See discussions, stats, and author profiles for this publication at: https://www.researchgate.net/publication/336270678

\title{
Systemic financial risk indicators and securitised assets: an agent-based framework
}

Article in Journal of Economic Interaction and Coordination · October 2019 DOI: 10.1007/s11403-019-00268-z

CITATION

1

5 authors, including:

Andrea Mazzocchetti

Università degli Studi di Genova

8 PUBLICATIONS 41 CITATIONS

SEE PROFILE

Marco Raberto

Università degli Studi di Genova

85 PUBLICATIONS 2,481 CITATIONS

SEE PROFILE
READS

51

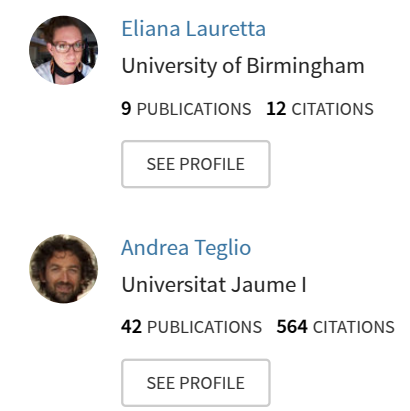

Some of the authors of this publication are also working on these related projects:

Green Lending, CEO Power and Financial Stability View project

Assessing the impact of green fiscal and monetary policies on financial risk View project 


\section{MPRA \\ Munich Personal RePEc Archive}

\section{Systemic Financial Risk Indicators and Securitised Assets: an Agent-Based Framework}

Mazzocchetti, Andrea and Lauretta, Eliana and Raberto,

Marco and Teglio, Andrea and Cincotti, Silvano

University of Genoa, University of Birmingham, University of Genoa, University Ca' Foscari of Venice, University of Genoa

24 October 2018

Online at https://mpra.ub.uni-muenchen.de/89779/

MPRA Paper No. 89779, posted 30 Oct 2018 14:32 UTC 


\title{
Systemic Financial Risk Indicators and Securitised Assets: an Agent-Based Framework
}

\author{
Andrea Mazzocchetti ${ }^{\mathrm{a}}$, Eliana Lauretta ${ }^{\mathrm{b}}$, Marco Raberto $^{\mathrm{a}}$, Andrea Teglio ${ }^{\mathrm{c}, \mathrm{d}}$, Silvano Cincotti $^{\mathrm{a}}$ \\ ${ }^{a}$ DIME-CINEF, Università di Genova, Via Opera Pia 15, 16145 Genova, Italy \\ ${ }^{b}$ Department of Finance, Birmingham Business School, University of Birmingham, University House, Edgbaston Park Road, \\ Birmingham B15 2TY, UK \\ ${ }^{c}$ Department of Economics, University Ca' Foscari of Venice, Cannaregio 873, 30121 Venezia, Italy \\ ${ }^{d}$ Universitat Jaume I, Campus del Riu Sec, 12071 Castellón, Spain
}

\begin{abstract}
The paper presents an agent-based model of a credit economy which includes a securitisation process and a bailout mechanism for banks' bankruptcies. Within this model's framework banks are able to sell mortgages to a Financial Vehicle Corporation, which finances its activity by creating Mortgage-Backed Securities and selling them to a mutual fund. In turn, the mutual fund collects liquidity by selling shares to households and remunerating them with a monthly interest rate. The impact of this mechanism is analysed by means of computational experiments for different levels of securitisation propensities of banks. Furthermore, we study a set of systemic risk indicators which have the aim to assess financial imbalances within the financial system. Two of them are the mortgage-to-GDP ratio and the Capital Adequacy Ratio which are constructed to detect only the in-balance sheet changes in banks' credit exposure. We consider two additional indicators, similar to the previous ones with the only difference that they are able to account also for the off-balance sheet items. Moreover, we introduce a novel indicator, the so-called VUC indicator, which also targets the off-balance assets. Results confirm that higher securitisation propensities weaken the financial stability of banks with relevant effects on different sectors of the economy. Most important, the analysis of systemic risk reveals the important issue of designing suitable systemic risk indicators for predicting incoming financial crises, finding that an essential feature of these indicators should be to integrate banks' off-balance sheet assets.
\end{abstract}

Keywords: sytemic financial risk indicators, securitisation, housing market, agent-based models

JEL classification: C63, R31, G21, G23

Email addresses: andrea.mazzocchetti@edu.unige.it (Andrea Mazzocchetti), e.lauretta@bham.ac.uk (Eliana Lauretta), marco.raberto@unige.it (Marco Raberto), andrea.teglio@unive.it (Andrea Teglio), silvano.cincotti@unige.it (Silvano Cincotti) 


\section{Introduction}

The paper contributes to the literature of macro-financial agent-based models, financial innovation and systemic risk. The study aims to answer the question of why financial risk indicators, with a particular focus on those detecting financial instabilities, remain only partially able to identify in time and quantify the actual financial system risk exposure. The models applied so far for detecting financial imbalances (e.g. see Borio and Lowe, 2002a; Misina and Tkacz, 2009; Barrell et al., 2010, among others) still present large errors in their predicting power (ECB, 2011; Deghi et al., 2018).

We analyse five systemic risk indicators which have the aim to assess financial imbalances within the financial system. Two of them are the well-known mortgage-to-GDP ratio and the Capital Adequacy Ratio ${ }^{1}$ (e.g. see Borio and Lowe, 2002a; Barrell et al., 2010), which are constructed to detect only the in-balance sheet (in-BS) changes in credit exposure of the banking sector (CAR) and the financial system as a whole (credit-to-GDP). We consider two additional indicators, similar to the previous ones with the only difference that they are able to account also for the off-BS items. We call them adjusted mortgages-to-GDP and adjusted CAR. Moreover, we introduce a last indicator, so-called VUC indicator (see Lauretta et al. (2016)), which also targets the off-balance sheet (off-BS) assets.

Usually, banks decide to forward the off-BS items to the securitisation process to reduce the level of risk exposure of their credit portfolio. We analyse these indicators and compare the in-BS and off-BS dimensions in the context of the agent-based macroeconomic simulator Eurace (Cincotti et al., 2010, 2012a; Raberto et al., 2012; Teglio et al., 2017). To the best of our knowledge, this is the first time that in-BS and off-BS measures to detect financial imbalances are analysed and implemented in an agent-based economy.

Eurace reproduces an artificial macroeconomy integrating different sectors and markets populated by heterogeneous and bounded rational agents. Each agent is characterised by a double-entry balance sheet (i.e. the "balance sheet approach" described in Teglio et al. (2010)) which enables us to observe the debts-credits dynamics in- and off-balance sheet and, thus to take account of those dynamics in the assessment of the systemic financial risk. We use this model for its peculiarity to reproduce real-world economic dynamics in a simplified but still rich way. In fact, it presents the ideal environment for the study of the out-of-equilibrium and non-linear dynamics of the economy.

The version of Eurace presented here includes a housing market in the style of Ozel et al. (2016), and a securitisation mechanism on the footprints of Mazzocchetti et al. (2018) and Lauretta (2018) that allows banks to free up their balance sheets from risk-weighted assets and circumvent the prudential capital requirements. A behavioural rule governs the model: the securitisation propensity. It is introduced as an exogenous parameter and determines the level of banks' resort on the securitisation. To higher values of the securitisation propensity corresponds a higher resort to securitisation. Moreover, the model shows a bailout resolution

\footnotetext{
${ }^{1}$ Actually we use the leverage of the bank as risk indicator, defined as $1 / C A R$. In this way, the indicator should increase with systemic risk, coherently with the other indicators.
} 
mechanism for banks' bankruptcies, which foresees the banks' rescue by means of government spending if banks' equity becomes negative (see Section 3.2 for more details).

In the aftermath of the crisis, the management of banks breakdowns has been a major concern for the public institutions of most developed countries around the globe. In the last decade, sovereign States and international organisations coped with the burden of the threat of banks' failures and employed several policy tools to bring back the economic system to a certain level of stability. Moreover, some financial institutions turned out to be "too big to fail", therefore government interventions became vital. To give an example, the US government intervened in 2008 with the TARP ${ }^{2}$ (Troubled Asset Relief Program) allowing the Treasury to purchase illiquid, difficult-to-value assets from banks, up to 475 billion dollars, de facto introducing the first financial system bailout. Accordingly, the Federal Reserve responded to the financial crisis by implementing unconventional monetary policies (see Guerini et al., 2018), that involved the purchase of mortgage-backed securities, bank debt and Treasury notes, reaching 2.1 trillion dollars in June 2010 ${ }^{3}$. During the banking crises, also several European governments organised rescue packages to support banks, which involved 114 financial institutions during the period 2007-2013 (Gerhardt and Vennet (2017)).

We run simulations for a time span of 35 years. The results show that increasing the value of securitisation propensity enhances the amount of off-BS mortgages transferred to the securitisation process, while reducing the amount hold in-BS and, thus increasing, once the boom and bust occurs, the intensity of a recession, given a higher credit exposure of the whole financial system. The securitisation mechanism allows banks to exploit regulatory capital arbitrage and impact on their CAR. Consequentially, they can avoid increasing their equity and remain able to continue to meet the capital requirements while their overall systemic risk grows.

The bailout mechanism introduced in the model reproduces well what we witnessed in the last decade after the Global Financial Crisis (GFC). It shows the effect of the securitisations process on government accounting and how the costs of a bailout fall on the taxpayers. Also, we can observe the negative effects of the increased risk exposure of the credit market on the housing market and business cycle dynamics (see Section 5 for more details on this particular point).

Moreover, we compute the systemic risk indicators mentioned at the beginning of this introduction, and the outcomes show that banks can satisfy the capital requirement while they keep building-up gradually a higher risk exposure. The mortgages-to-GPD and CAR in their original version do not detect the development of the increasing exposure because they monitor only the in-BS dynamic and they do not consider the off-BS items. Therefore, this two indicators can become misleading. However, the adjusted version of mortgagesto-GDP and CAR together with the VUC indicator seem more adequate to monitor and anticipate this risk exposure (see Section 5).

\footnotetext{
${ }^{2}$ see https://www.treasury.gov/initiatives/financial-stability/TARP-Programs/Pages/default. aspx

${ }^{3}$ see https://www.federalreserve.gov/monetarypolicy/bst_recenttrends.htm
} 
The discussion on the effectiveness and reliability of the systemic risk indicators has been particularly lively so far, both for what concerns timing and impact on the real economy (see Section 1). Certainly, the costs of banks' bailout have been high for the entire economy and mostly burdened on taxpayers. Therefore, it is of the utmost importance to develop and study better indicators which could time and prevent the increase of the systemic risk in the economy.

The remainder of the paper is organised as follows. Section 1 presents a brief review of the systemic risk indicators and explains how they are used in this study. Section 2 and 3 review the main elements of the Eurace model and describe in details the novel modelling features. Sections 4 and 5 shows the results of computational experiments and discuss them. Section 6 concludes the paper with final remarks. 


\section{Literature review}

It is extremely important to have timely and effective measures of systemic financial risk assessment because they are central to macro-prudential supervisory and regulatory policies. This means that there is the need for tools and models able to monitor, capture and evaluate potential risks that can build up financial instabilities within the financial system. Usually, the notion of systemic financial risk is associated with assessing the total size of the risk present at a certain point in time within the financial system (Schwaab et al., 2011), namely the time-varying probability of a systemic event. It is characterised by both crosssectional (how risks are correlated across financial institutions) and time-related dimensions (how systemic risk evolves over time given a change in certain business and market conditions) (Bandt et al., 2012; Adrian and Brunnermeier, 2016).

In the past, the Value at Risk (VaR) was the most common measure of risk used by financial institutions and authorities, and it was able to analyse the single institution's level of risk. However, this measure was unable to capture the single institution's contribution to the overall systemic risk and the ensuing crosssectional dimension of the systemic risk (Adrian and Brunnermeier, 2016). In the aftermath of the global financial crisis (GFC) the Governments, Central Banks, and other Financial Authorities have been dealing with the cumbersome process to bring back the financial system to certain degrees of stability and recover the damaged economies of the countries involved. The debate, in both academic and non-academic level, started questioning systemic risk methodologies (e.g. see Acharya et al., 2017; Adrian and Brunnermeier, 2016; Banulescu and Dumitrescu, 2015; Diebold and Yilmaz, 2014; Billio et al., 2012; Goodhart and Segoviano, 2009; Huang et al., 2009). For example, the European Central Bank (ECB, 2011) in its Financial Stability Review of June 2011 contributed to this open discussion and introduced three models, each focusing on different aspects of systemic risk. The first aimed to apply a multivariate regression quantiles to assess the contribution of each financial institution to systemic risk. The second used macro and credit risk data in order to detect financial institutions shared exposure to common observed and unobserved drivers of financial distress. Finally, the third one provided a coincident indicator of systemic risk by aggregating information from different segments of the overall financial system. More recently, in the Financial Stability Review of the ECB in 2018, Deghi et al. (2018) propose a Financial Stability Risk Index (FSRI) for the Euro area, which forecasts the near-term risk for the economy to fall into a deep recessions. The index power is derived from the extraction of the co-movement information of a combination of a large set of macro-financial indicators and taking into account also the role of spillovers and contagion risk.

A relevant section of the literature in systemic risk focuses on identifying those systemically important institutions that can trigger systemic instability in the financial system. A branch of the literature has used

contingent claims analysis in order to assess systemic risk (e.g Lehar, 2005; Gray et al., 2008). However, this approach presents a downside given the strong assumptions imposed concerning the banks' liability structure. Other scholars have relied instead on market data (Huang et al., 2012; Adrian and Brunnermeier, 2016; Billio 
et al., 2012, among others). An important contribution to mention is that of Acharya et al. (2017) who assume that undercapitalization of the financial sector as a whole produces negative externalities which can impact on the real economy. They measure the single bank's contribution to systemic risk as its propensity to be undercapitalized when the whole system is undercapitalized, i.e. systemic expected shortfall (SES). SES increases in the institution's leverage and its marginal expected shortfall (MES). Adrian and Brunnermeier (2016) introduced CoVar, which they define as "the difference between the Conditional Value at Risk (CoVaR) of the financial system conditional on an institution being in distress and the CoVAR conditional on the median state of the institution." Huang et al. (2009, 2012) developed a systemic risk indicator measured by the price of insurance against systemic financial distress. It assesses the single bank's (or group of banks) marginal contribution and identifies the systemic importance of each bank to the systemic risk. The authors refer to this indicator as Distress Insurance Premium (DIP). Moreover, the post-crisis literature on systemic financial risk (e.g. Trichet, 2009; ECB, 2009, 2011; Bandt et al., 2012) distinguished three main (but linked to each other) sources of financial instability: contagion, shared exposure to financial markets or macroeconomic risks, and financial imbalances. Contagion risk is defined as an initially idiosyncratic market disturbance which become widespread in the cross-section over time and is led by price co-movement on the downside. Shared exposure to financial market or macroeconomic risks is the situation where adverse conditions of the financial markets or the macroeconomy may impact on financial intermediaries and markets and cause simultaneous negative effects. Finally, financial imbalances occur in presence of boom and bust of credit or other asset prices. For the purpose of this study, we will focus our attention on the financial imbalances in particular. They are not easy to detect and quantify, given that they can arise and develop gradually over time without producing any relevant change in inflation.

Among the most common measures, the literature often refers to the Credit-to-GDP ratio and the Capital Adequacy Ratio (e.g. see Borio and Lowe (2002a), Barrell et al. (2010)) to assess systemic risk. The first measure detects the credit exposure of the entire financial system with respect to GDP, while the second, also known as the capital to risk-weighted assets (RWA) ratio, measures the banking sector credit exposure with respect to its available capital. However, all the systemic measures discussed above rely mostly on in-BS data and asset prices and do not take into account the role played by other variables, such as the off-BS assets. The latter permits banks to hedge their idiosyncratic risk and presents the peculiarity, through the securitization process, of amplifying financial imbalances within the financial system while keeping volatility low (i.e. what Brunnermeier and Sannikov (2014) define the "volatility paradox") by impacting on the Capital Adequacy Ratio and favouring the creation of endogenous multi-leverages (Lauretta, 2018). As a consequence, the financial system, as a whole, results in a higher risk exposure which is only partially detected by the available systemic risk measures. 


\section{Model}

The model presented in this paper to conduct our investigation is the agent-based macroeconomic model Eurace (see Cincotti et al., 2012a; Raberto et al., 2012; Teglio et al., 2017; Petrovic et al., 2017; Ponta et al., 2018).

In general, agent-based models (ABM) have been widely used in the last decade in many economic fields ${ }^{4}$, including macroeconomics (see e.g. Delli Gatti and Desiderio, 2015; Caiani et al., 2016; Dawid et al., 2018; Dosi et al., 2017). One of the main advantage of the ABM approach relies on the opportunity to study the emergent aggregate statistical regularities in the economy, which are not originated by the behavior of an "average" and rational individual, but are the result of agents' behavior and interactions ${ }^{5}$.

Eurace model represents a fully integrated macroeconomy composed by several agents that act following behavioral rules and interact through various markets. Each agent is characterised by a double-entry balance sheet that includes the details of all assets and liabilities (Table 8). The dynamical change of agents' balance sheet entries depends on agents' plans and on the result of agents' interaction within the different market settings. Figure 1 provide an overview of the model, showing the main agents and their interactions through markets. Arrows directions indicate the role that agents take in the markets, i.e. demand or supply.

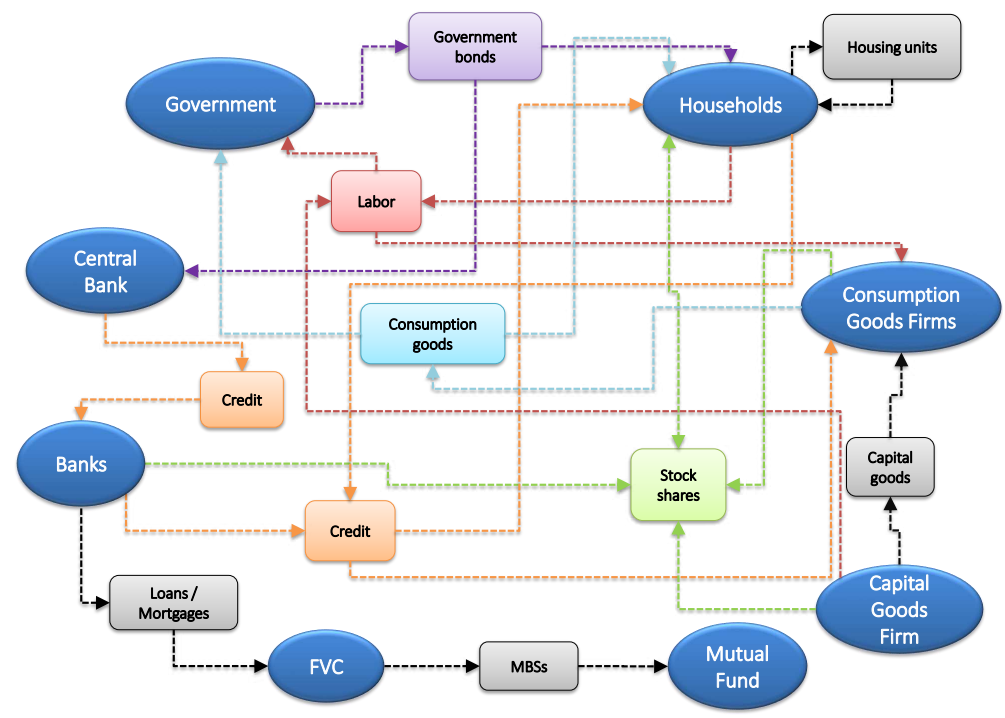

Figure 1: Eurace model overview. Round boxes include agents, while rectangular boxes include markets. The outgoing arrows represent the supply and incoming arrows represents the demand

In the model agents' decision processes are characterized by bounded rationality and limited capabilities of computation and information gathering; thus, agents' behavior follows adaptive rules derived from the management literature about firms and banks, and from experimental economics literature about the behavior

\footnotetext{
${ }^{4}$ See Fagiolo and Roventini (2017) for a survey and a comparison with DSGE models

${ }^{5}$ For instance, in Eurace small idiosyncratic shocks at the firm level may generate single firm bankruptcies, which cause credit rationing by banks and so waves of bankruptcies among firms, and then entailing large aggregate fluctuations in the economy.
} 
of consumers and financial investors (Teglio et al., 2010; Raberto et al., 2012; Cincotti et al., 2012b; Teglio et al., 2017). In general, agents interact in different types of markets, i.e. market for consumption goods and capital good, housing market, labor market, credit market, securitisation market and financial market for stocks and government bonds (figure 1). Most markets are based on a decentralized exchange with pairwise trading, thus allowing us to capture some realistic features of goods, labour and credit markets, like price dispersion, exchange out of equilibrium and rationing.

Furthermore, the balance sheet approach (Teglio et al., 2010) allows us to ensure the consistency at any time step between stocks and flows in the model, both at the level of the single agent and at the aggregate one, in line with the post-Keynesian stock-flow-consistent modeling approach (Godley and Lavoie, 2012). Macroeconomic agent-based stock-flow constistent models have been developed up to date only in few works (Kinsella et al., 2011; Riccetti et al., 2015; Caiani et al., 2016). In particular, Caiani et al. (2016) build a general and flexible benchmark macroeconomic AB-SFC model, where the economy is fully decentralized and all transactions between private agents occur through local interactions based on matching protocols. The stock-flow consistency of a model allows to check that all monetary and real flows are accounted for, and that all changes to stock variables are consistent with these flows ${ }^{6}$.

\section{Novel modelling features}

In this study, we aim to assess the systemic risk arising from the securitisation practise. For this purpose, we enriched Eurace model with an improved securitisation process and a bank resolution mechanism, which allows us to evaluate the risks for the whole economy entailed by banks' bankruptcies. In the following, we provide a description of the core modelling features related to this work, highlighting the new developments.

\subsection{Securitisation process}

The securitisation mechanism used in this paper is an enhancement of the one proposed in Mazzocchetti et al. (2018). In particular, we have introduced an endogenous demand for mutual fund (MF) equity shares, enabling the MF to finance its activity by issuing new shares, that can be purchased by households using part of their monthly disposable income. This demand side specification plays a crucial role in the securitisation functioning, since a restraint in MF liquidity hampers its capacity to purchase MBSs, thus forcing the banks to retain unwanted credit in their balance sheet.

We recall here the main characteristics of the securitisation process, focusing on the mortgage case, and then introduce the new features. The choice to securitise only mortgages relies on the opportunity to take into account the prepayment risk, i.e. the risk that households pay off their mortgages through housing units' fire sales when financially distressed (a description of the housing market is recalled in the appendix,

\footnotetext{
${ }^{6}$ A detailed description of Eurace balance sheet matrices is provided in the appendix.
} 
for further details and related computational experiments with the housing market, see Ozel et al. (2016)). The prepayment of mortgages plays a crucial role in the securitisation market, mainly for two reasons:

- Prepayments reduce the amount of mortgages in banks' balance sheet; thus, a wave of mortgage prepayments triggered by housing units' fire sales may hamper banks' possibilities to sell the desired amount of mortgages to the FVC.

- Prepayments reduce the profits of banks and, if securitisation is active, also of the mutual fund. In fact, whenever a mortgage is payed off the payments of its interest stops.

Securitisation mechanism allows banks to free up their balance sheet from mortgages and their related risk by selling them to a Financial Vehicle Corporation (FVC), which finances its activity by creating MortgageBacked Securities (MBSs) and selling them to a MF. Since Eurace includes a capital requirement provision that mimics Basel II regulations, banks can exploit the securitisation process to reduce the risk weighted assets in their balance sheet, thus complying with capital requirements without increasing their equity.

In the following, we describe the mortgage lending process and the securitisation framework. Let us consider a bank $b$ with equity $E_{b}$ and risk-weighted portfolio $W_{b}$, consisting of risk weighted loans $W_{b, \mathcal{L}}$ and mortgages $W_{b, U}$, such that:

$$
W_{b}=W_{b, \mathcal{L}}+W_{b, U}
$$

A household $h$ can send a credit requests to banks. Whenever it enters in the housing market, it can buy house units and, in case its liquidity is lower than the offered price, it asks for a mortgage. Let us assume that $\widehat{U}_{b h}$ is the mortgage asked by the potential borrower (household $h$ ) to the bank $b$. Bank $b$ can grant the mortgage amount $\widehat{U}_{b h}$ to household $h$ only if is endowed with an amount of equity which is higher than a fraction of the risk-weighted assets in its balance sheet, i.e. it satisfies the capital requirement:

$$
E_{b} \geqslant k\left(W_{b}+\omega_{\widehat{U}_{h}} \widehat{U}_{b h}\right)
$$

where $k$ is fixed and equal to $0.1^{7}$. Moreover, risk weight of household mortgages $\left(\omega_{\widehat{U}_{h}}\right)$ is assumed constant and equal to $70 \%^{8}$.

As stated in equation 2, bank's lending activity is limited by the ratio of its risk-weighted assets and equity. The ceiling of risk-weighted assets for the bank is given by $\alpha$ times its equity capital, i.e. $\alpha E_{b}$, where $\alpha=\frac{1}{k}$. Thus, from a regulatory perspective, bank is constrained by the following rule: $W_{b} \leq \alpha E_{b}$. With the introduction of the securitisation mechanism, the bank can put off its balance sheet the amount of riskweighted assets that exceed the ceiling; thus it could keep lending whenever $W_{b}$ exceeds $\alpha E_{b}$. However, we

\footnotetext{
${ }^{7}$ For a study of the effects of different capital requirements in Eurace see Raberto et al. (2012)

${ }^{8}$ We refer to the standardised approach to credit risk outlined in Basell III reform, where residential real estate exposures only adjust on Loan to Value ratio(LTV), which we assume constant and equal to $100 \%$ (see BIS (2017)).
} 
want to consider a behavioral specification that allows the bank to sell credit when it approaches the ceiling, thus considering different thresholds, computed quarterly as a fraction of the ceiling. For this purpose, we introduce an exogenous securitisation propensity parameter $\mu \leq 1$. According to $\mu$, the bank's threshold is given by $(1-\mu) \alpha E_{b}$. The higher the value of $\mu$, the lower will be the threshold of the bank, resulting in more securitisation. In fact, whenever bank's risk-weighted assets exceed the threshold, the bank computes the amount $S_{b}$ of risk weighted assets that it want to sell to the FVC as:

$$
S_{b}=W_{b}-(1-\mu) \alpha E_{b}
$$

Conversely, $S_{b}$ is set to zero (no securitisation), if bank's risk-weighted assets do not exceed the threshold.

We define $U_{b}$ as the amount mortgages in bank $b$ balance sheet. It is worth remarking that $W_{b}$ is the sum of risk-weighted loans $\left(W_{b, \mathcal{L}}\right)$ and risk-weighted mortgages $\left(W_{b, U}\right)$; thus $S_{b}$ is computed including also the risk-weighted loans. However, we securitise only mortgages, which in extreme cases may be not enough to fully satisfy the bank's planned sales.

The amount of mortgages $\left(U_{S_{b}}\right)$ that the bank sell to the FVC is computed as the ratio between $S_{b}$ and the bank's risk-weighted mortgages and is uniformly distributed among bank's mortgages. In particular:

$$
\left\{\begin{array}{lll}
U_{S_{b}}=\left(\frac{S_{b}}{W_{b, U}}\right) U_{b} & \text { if } & W_{b, U}>S_{b} \\
U_{S_{b}}=U_{b} & \text { if } & W_{b, U} \leq S_{b}
\end{array}\right.
$$

FVC funds the purchase of loans and mortgages by issuing mortgage-backed securities (MBSs), that are sold to the MF. In the same fashion of Mazzocchetti et al. (2018), the MF is endowed with an initial provision of liquidity that allows it to purchase an amount of securitised products for two quarters, given a $\mu$ equal to $100 \%$. Furthermore, the fund aims at maintaining its liquidity at the target level $\left(M_{D}^{*}\right)$, which represents the amount of "operating liquidity" that is needed to carry out the securisation process for a quarter with $\mu$ equal to $100 \%$.

Each quarter, mutual fund computes its liquidity needs $L_{D}$ as:

$$
\left\{\begin{array}{lll}
L_{D}=M_{D}^{*}-M_{D} & \text { if } & M_{D}^{*}>M_{D} \\
L_{D}=0 & \text { if } & M_{D}^{*} \leq M_{D}
\end{array}\right.
$$

where $M_{D}$ is the current liquidity of the fund. Therefore, $L_{D}$ represents the amount of liquidity that the fund should rise. To do so the mututal fund can issue new equity shares, that generally are purchased by households.

The rationale behind the use of a liquidity target relies on the choice to avoid a direct relation between quarterly securitisation and the issuing of new shares, which would give rise to frequent shocks on households' disposable income. On the contrary, a liquidity target let the fund to periodically adjust the liquidity level in order to have always enough resources to purchase ABSs and MBSs. Therefore, the fund uses the liquidity 
simply as a buffer for its securitisation activity, but relies on share issuing for financing new purchases.

The mutual fund computes quarterly the liquidity needed to reach its target, and, accordingly, issues new shares that are bought by the households at the face value ${ }^{9}$. Moreover, the mutual fund remunerates the owners of the issued shares paying a monthly interest, given by the central bank policy rate plus a spread $s_{D, t}$. To some extent the mutual fund may be considered as a fund whose benchmark is the policy rate, which is outperformed by the spread $s_{D, t}$. A minimum spread value $\varpi$ is fixed, so that the mutual fund always pays an interest that is higher than the policy rate. However, when new shares are to be issued, the spread is increased by the mutual fund until it fulfills its liquidity needs. Accordingly, the spread is reduced when the fund has enough liquid resources.

In order to link the spread to the fraction of disposable income that households are willing to invest in equity shares, we enriched the behavioral specification of the demand side of mutual fund's shares by including the following relation:

$$
b_{t}=\min \left(\eta s_{D, t}, \varrho\right)
$$

where $b_{t}$ is the fraction of disposable income that households use to purchase new shares, ${ }^{10} \varrho$ is the maximum income percentage that households can invest and $\eta$ is a parameter which represent the marginal propensity of households' investments in new shares with respect to the spread. In this setting, $\eta$ is equal to 15 ; thus for each yearly percentage point offered by the mutual fund as a spread on the policy rate, households spend the 15 percent of their monthly disposable income to purchase the shares. Although the securitisation is active on a quarterly base and the liquidity needs $L_{D}$ are updated accordingly with the same timing, the issues of new shares occur monthly, in order to smooth the purchases across the quarters. The shares bought by households give them the right to receive the earnings of the mutual fund, which are given by the interest payments on the mortgages associated with securitised products.

It is worth remarking that the purchase of ABSs and MBSs by the mutual fund in the model is not $100 \%$ guaranteed. In particular, households are available to buy mutual fund's shares only within a certain

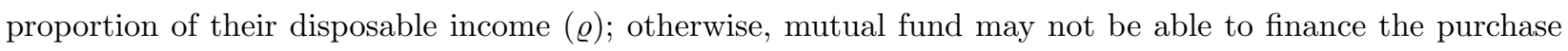
of ABSs and MBSs and securitisation stops until new funds are raised by the mutual fund.

\subsection{Bailout}

In order to tackle banks' bankruptcies, we introduce a bailout mechanism which is activated whenever the banks' equity becomes negative.

It is worth remarking that, whenever credit rationing occurs, banks increase their equity by retaining

\footnotetext{
${ }^{9}$ The face value is computed as the ratio between the nominal value of the mutual fund assets divided by the number of outstanding shares.

${ }^{10}$ Thus the shares are distributed among households proportionally to their disposable income.
} 
their earnings, with the aim to comply with the capital requirement $\left(W_{b} \leq \alpha E_{b}\right)$ and grant more credit. However, bank's equity may be reduced by loans and/or mortgages write-offs, which can occur in case of GCPs bankruptcies or severe financial distress of households. If write-offs are high enough to make banks' equity fall down below zero, the government intervenes by recapitalising the banks for an amount that allows the credit institutions to re-comply with capital requirements.

Therefore, in this setting the cost of banks' bankruptcies is supported by government and finally burden the tax payers. In fact, the fiscal policy pursued by government is the stability and growth pact (SGP), which targets a deficit to GDP raito of $3 \%$. The bailout costs increase government spending and most likely its deficit to GDP ratio, bringing it to override the target compelling the government to increase tax rates. 


\section{Computational experiments}

Results are obtained by performing Monte Carlo computational experiments, i.e., simulations are run using different seeds of the pseudorandom number generator for each scenario. Following Lauretta (2018) and Mazzocchetti et al. (2018), we set five values of the securitisation propensity $\mu(0 \%, 5 \%, 10 \%, 20 \%, 30 \%)$. Simulations have a duration of 35 years and are replicated using 50 different seeds per scenario, for a total of 250 simulation runs. The computational experiments have been performed with the following settings: 3000 households, 50 Consumption Goods Producers, 3 Banks, 1 Capital Good Producer, 1 Financial Vehicle Corporation, 1 Mutual Fund, 1 Government and 1 Central Bank.

Even though simulations run for a time span of 35 years, for the first five years banks are not allowed to sell credit to the Financial Vehicle Corporation, thus there are five common years of transition phase, which we do not consider in the analysis. Trajectories can diverge at the beginning of year 6 , when banks can sell mortgages to the FVC and the distinction among securitisation scenarios is enabled.

We present results using the median of yearly averages (computed across different time windows) over the seeds for each one of the considered scenarios. In particular we show, for each of the five values of $\mu$ $(0 \%, 5 \%, 10 \%, 20 \%, 30 \%)$, the median of economic and financial variables over the 50 seeds, along with the first and the third quartile. In the description of results, in-BS mortgages represent the mortgages accounted in banks' balance sheet, while off-BS mortgages are the mortgages securitised and put off banks' balance sheet. Total mortgages represent the sum of in-BS mortgages and off-BS mortgages. Furthermore, in order to better distinguish between monetary and non-monetary variables, in the figures we use the symbol "E€" (Eurace Euro) to refer to the currency unit in the model (see (see Ponta et al., 2018).

Moreover, to the aim of our investigation, we analyse a set of five indicators: banks' leverage, i.e the ratio between banks' weighted assets and equity, computed using only in-BS weighted assets and total weighted assets; mortgages to GDP ratio, computed using only in-BS mortgages and total mortgages; a fifth indicator, the so-called VUC indicator (see Lauretta et al., 2016, and Eq. 7):

$$
V U C=\frac{\frac{\sum_{b=1}^{N} T C_{T}}{E q^{b}}}{G D P}
$$

This indicator can be seen as a transformation of the mortgage-to-GDP indicator in which the numerator expresses the ratio between the sum of the portion of banks credits $T C_{T}$ forwarded to the securitisation process (off-BS assets) and the total bank's equity $E q^{b}$. Following the common practice in the literature (e.g. see Borio and Lowe, 2002a,b; Drehmann and Juselius, 2014), the GDP is used to scale the indicator. The mortgage-to-GDP takes into account the leverage applied at the commercial bank level, but ignores the role played by other leverages operating within the financial system at different levels. The VUC indicator simply detects a second order of leverage, representative of the multi-leveraging effect operating within the financial sector, which can trigger systemic financial risk. This indicator has a relevant obsevartory power and improves recognition of systemic-risk-building-up dynamics in particular for what concernes the off-BS 
flows. For policy purposes, the VUC indicator used together with the most common mortgage-to-GDP ratio can improve the early-warning detection of financial imbalancies in the financial system.

Finally, it is worth remarking that the indicators, differently from the other variables, are presented using the median, the first and the third quartile of yearly values (computed only in certain years, i.e. year 1 , $5,10,15,20,25,30$ after securitisation starts) over the seeds for each one of the five values of $\mu(0 \%, 5 \%$, $10 \%, 20 \%, 30 \%)$. The reason is given by the need to consider the yearly values of the indicators in order to compute the cross-correlations. In fact, we present a cross-correlation analysis between the indicators and the yearly number of bankruptcies. Moreover, we add a cross-correlation measure between mortgages-to-GDP indicators and the yearly number of firesales. Therefore, in order to correctly perform the cross-correlations analysis, we consider the yearly time series of the indicators.

\section{Results}

Results of the computational experiments show the economic impact of the securitisation process across time, focusing on the effect on the housing market and, more in general, on a selection of relevant economic variables. In the specific context of securitisation, we also introduce and test a set of systemic risk indicators, that should be used as early warning for incoming financial crises.

In the next sections, we describe first the main economic implications of the securitisation process, analysing the specific effect of different securitisation propensity $(\mu)$, and finally we examine the effectiveness of the proposed risk indicators.

\subsection{The securitisation mechanism}

As outlined in section 3.1, the securitisation process involves banks, a financial vehicle corporation (FVC) and a mututal fund (MF). The latter is provided with an intial amount of liquidity which covers two quarters of securitisation with $\mu$ equal to $100 \%$. Moreover, the MF targets a liquidity threshold, under which new equity shares are issued and sold to households.

Figures 2 and 3 show the effects of the different scenarios on the MF. Scenarios with a higher value of $\mu$ show higher purchases of mortgage-backed securities (panel (b)) which are financed by means of both internal resources and by issuing of new equity shares (panels (a) and (c)). However, households' monthly income percentage that can be invested in shares' purchase is limited, thus an excess supply of MBSs may not be sustained by the fund, and banks could be rationed, i.e. not able to fulfill their planned credit sales (panel (d)).

Some details of the mutual fund equity shares are shown in figure 3. In particular, the mutual fund pays an interest rate to reward shareholders (panel (a) shows the yearly interest rate paid by the fund), and increases the spread whenever it needs to collect more liquidity, in order to attract more investors. This happens more frequently in the case of high securitisation scenarios, as the liquidity needed by the fund to buy new MBS is higher. The higher MF spread induce households to invest a more substantial fraction of 
their income in fund shares (panel (b)). It is worth remarking the interest rate of the MF shares is composed by the CB policy rate (panel (c)) and a spread. According to the MF interest rate, the mutual fund pays monthly dividends to the shareholders.

Figure 4 reports the main effects of the securitisation propensity on bank's balance sheet. For higher propensity $\mu$, banks sell more mortgages, thus reducing the amount of mortgages accounted in banks' balance sheet (panel (b)) and enlarging the off-balance sheet volume (panel (a)). Consequently, the proportion of off-BS mortgages over the total amount of credit enhances.

Securitisation allows banks to free up their balance sheet from risky assets, thus in the short run their capital adequacy ratio increases and more credit can be granted by the bank. Therefore, the growth rate ${ }^{11}$ of mortgages (which are securitised) is higher than the growth rate of firm's loans (which are not securitised), as shown in figure 6 .

Those findings are in line with the securitisation mechanism explained in section 3.1. In particular, according to equation 3, when securitisation is active banks de facto refer to their internal (adjusted) capital adeguacy ratio (CAR), avoiding the regulatory constraints ${ }^{12}$. In particular, the securitisation instrument allows banks to escape the capital requirement obligation, by selling risk-weighted mortgages to the FVC in exchange of liquidity. This aspect is highlighted in figure $10 \mathrm{~b}$, showing that bank leverage ${ }^{13}$ is much higher in the case of securitisation.

\subsection{Securitisation effects on credit and housing market}

In order to assess the impact of securitisation on lending activity and on the housing market, we analyse the total credit growth rate considering two different time horizons after the activation of the securitisation mechanism: a short one presenting the first five years and a long one, where we report all the 30 years.

Panels (a), (b) and (c) of figure 5 show an increase in the volume of total credit in the first five years. In fact, at the beginning of year 6 banks start to free up their balance sheets by selling risky assets, enabling the issuing of additional credit. After one year, mortgages growth rates are higher in the scenarios with positive $\mu$, showing that securitisation accelerates credit growth. As the paper focuses on the securitisation of mortgage loans, which means being able to expand the supply of mortgages, we set up a parametrization of the housing market where the demand by households is also sustained ${ }^{14}$. This is the main reason why the mortgage loans growth rate is more affected by securitisation propensity with respect to the firms' loans growth rate.

The effect of securitisation in the medium and long run is shown in figure 6 , and strictly depends on securitisation propensity $(\mu)$. In fact, the higher the value of $\mu$, the lower are credit growth rates in the long

\footnotetext{
${ }^{11}$ Growth rates are computed as the percentage increase of the selected indicator $I$ with respect to its value in year 5 , when securitization is enabled, i.e., $g(t)=(I(t)-I(5)) / I(5)$

12 in the current setting the capital requirement is fixed at $10 \%$.

${ }^{13}$ Bank leverage is the inverse of CAR, i.e., assets over equity. Here we refer to both in-BS and off-BS assets

${ }^{14}$ In particular, the value of the stock $T_{E T A}$ and flow $T_{D S T I}$ constraints is equal to 0.5 , while probability to enter in the housing market $\left(\Phi_{H}\right)$ is $50 \%$. For details on the effects of different parameterizations in the housing market see Ozel et al. (2016)
} 


\section{Mututal Fund data}

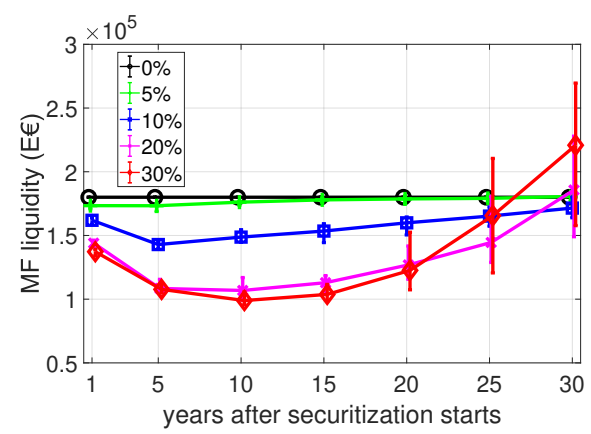

(a)

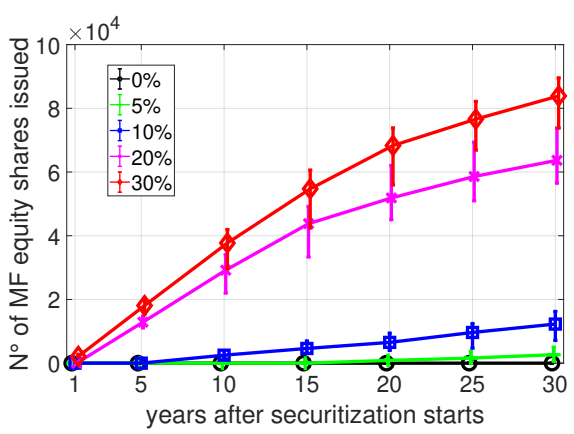

(c)

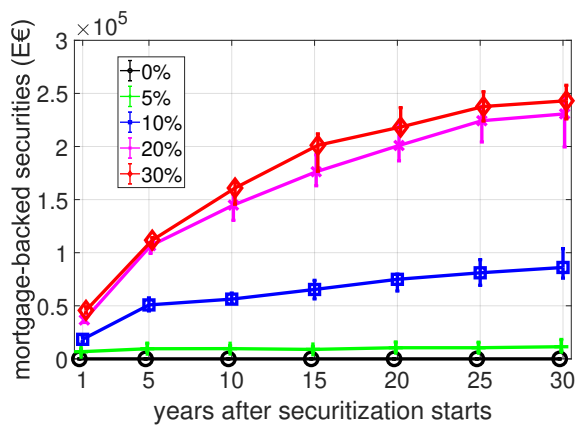

(b)

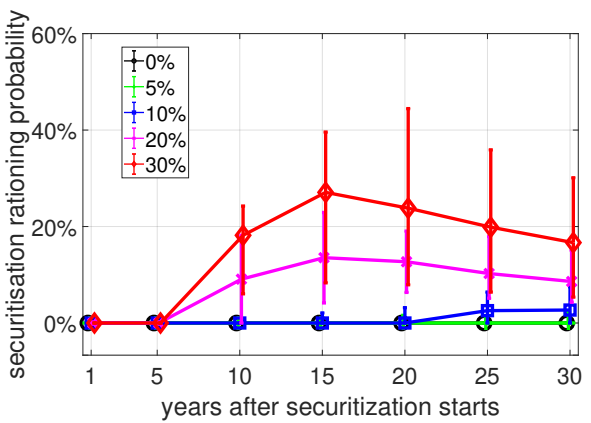

(d)

Figure 2: Yearly mean's median, first quartile and third quartile over 50 seeds of a set of mutual fund's data. Yearly means are computed across different time windows, each of them reported in the x-axis. Five securitisation propensity values $(\mu)$ are considered $(0 \%, 5 \%, 10 \%, 20 \%, 30 \%)$ 


\section{Mutual fund shares issuing}

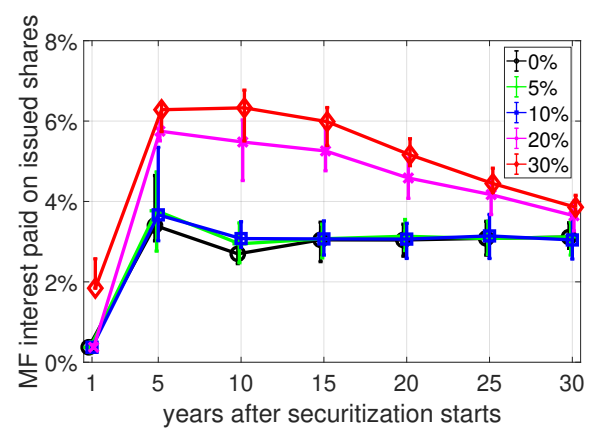

(a)

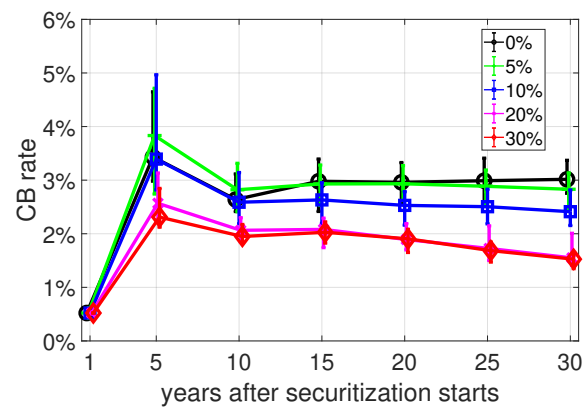

(c)

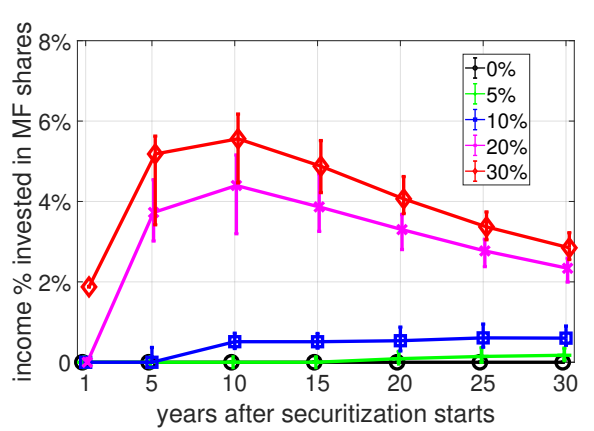

(b)

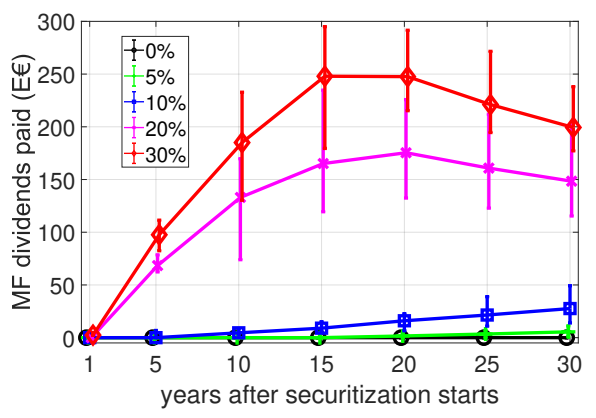

(d)

Figure 3: Yearly mean's median, first quartile and third quartile over 50 seeds of a set of mutual fund's shares issuing data. Yearly means are computed across different time windows, each of them reported in the x-axis. Five securitisation propensity values $(\mu)$ are considered $(0 \%, 5 \%, 10 \%, 20 \%, 30 \%)$ 
Banks' balance sheet data

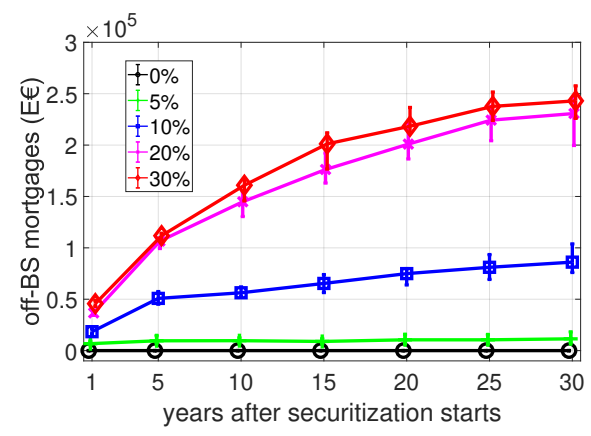

(a)

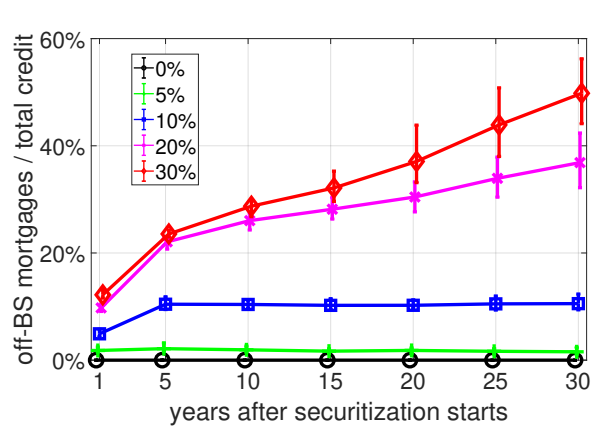

(c)

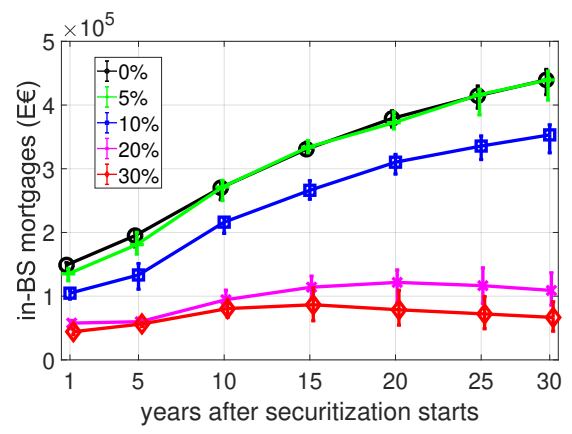

(b)

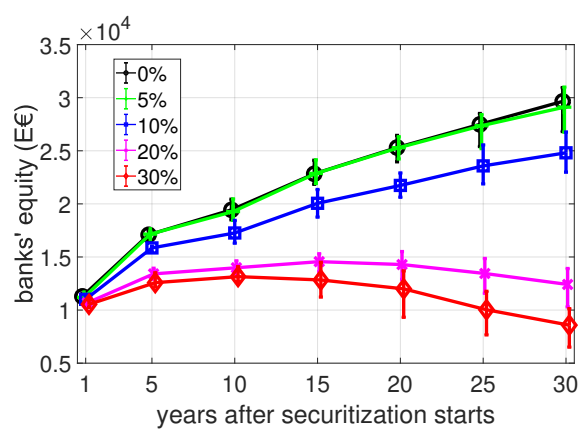

(d)

Figure 4: Yearly mean's median, first quartile and third quartile over 50 seeds of a set of banks' balance sheet data. Yearly means are computed across different time windows, each of them reported in the x-axis. Five securitisation propensity values $(\mu)$ are considered $(0 \%, 5 \%, 10 \%, 20 \%, 30 \%)$ 
run. This is mainly due to the higher instability triggered by the short-term boost of lending activity, not supported by an adeguate equity base increase, but built only on mortgages sales. In fact, securitisation may be impaired because the mutual fund does not have enough funds (panel (d) of figure 2) and when $\mu$ is high banks may find it difficult to increase their equity base by retaining earnings, since most of them flow out to off-BS mortgages. The results can be an increase in credit rationing (panel (a) of figure 7) and a decrease of loans and mortgages growth rate. Moreover, in the long run a low equity level increases the risk of banks bankruptcies due to credit write-offs.

The dynamics of the housing market is strictly linked with the mortgage volumes. In fact, the easier access to mortgage loans enhances the demand for housing units by households, triggering a boost in the housing price (panel (b) of figures 5 and 6). Following the dynamics of the mortgages, the housing unit price growth rate is larger in the short run (after securitisation has been enabled) and for higher values of securitisation propensity. However, in the medium and long run results may be reversed, with scenarios characterized by greater $\mu$ showing a slow down of the housing market activity, culminating in higher fire-sales volumes (figure $6 e)$.

It is worth noting that both in the credit and housing markets a low value of securitisation propensity $(\mu=5 \%)$ achieves the best results, boosting credit activity in the short run without suffering growth rate decreases in the long run with respect to the baseline scenario $(\mu=0 \%)$.

\subsection{Securitisation impact on firms}

The effects of securitisation process affect also the financing activity of firms. In particular, following the pecking order theory, Consumption Goods Producers (CGPs) first finance their production plan by means of internal resources, then they resort to bank credit, and finally, if rationed in the credit market, they issue new shares and sell them to households.

Thus, a boost or a restraint in banks' lending activity changes the financial structure of GCPs. In fact, as the securitisation process starts and banks are able to free up their balance sheet from risky assets, thus improving their capability to grant new loans to firms, CGPs face lower rationing in the credit market. Panel (a) of figure 7 illustrates this aspect, showing a reduction of credit rationing in the very first year after securitisation starts. However, in scenarios where the propensity $\mu$ is high, the lower bank equity level and the increase of fire-sales (figure 6e) that reduces the amount of mortgages in banks' balance sheet, may impair the securitisation process (see section 3.1) and increase the number of credit rationing in the medium and long run.

The higher frequency of firms rationed in the credit market leads to a higher number of illiquidity bankruptcies, where firms are no more able to roll over debt and finance their production plan (figure $7 \mathrm{~b}$ ).

\subsection{Securitisation effects on government accounting}

Figure 8 shows the impact that banks' defaults have on the government accounting. As stated in section 3.2, a resolution mechanism for banks' bankruptcies has been introduced in Eurace: if banks' equity becomes 


\section{Growth rates}

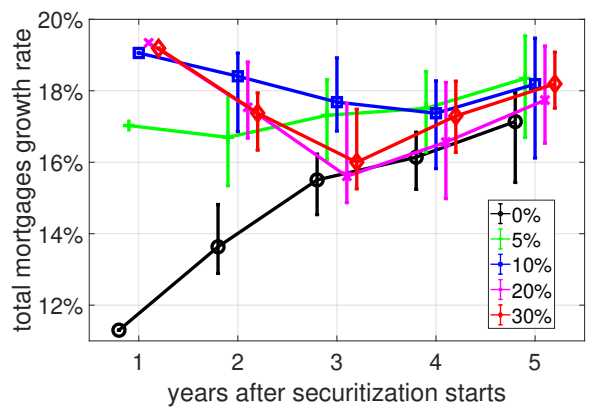

(a)

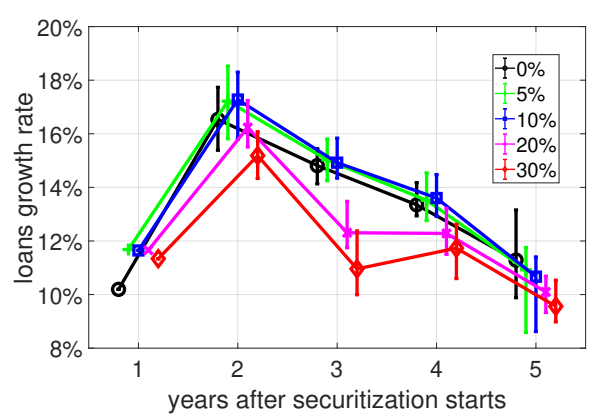

(c)

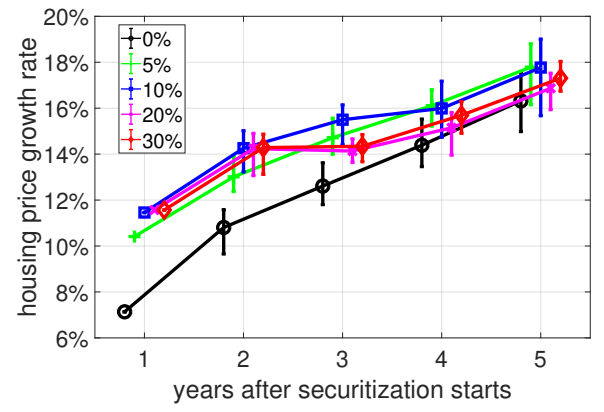

(b)

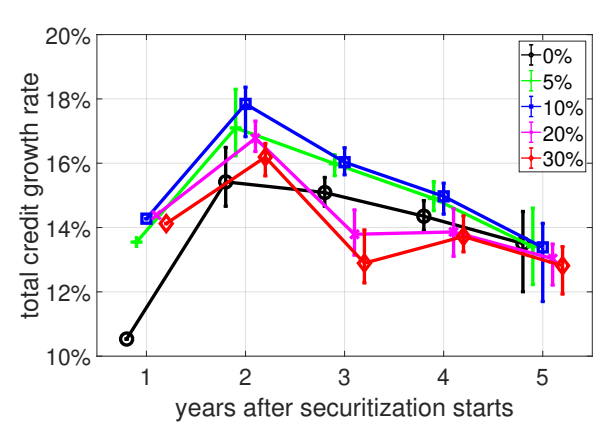

(d)

Figure 5: Growth rate's median, first quartile and third quartile over 50 seeds of credit and housing price. Growth rates are computed as the percentage increase of the selected variable in certain years (each of them reported in the x-axis) with respect to its value in year 5 . Five securitisation propensity values $(\mu)$ are considered $(0 \%, 5 \%, 10 \%, 20 \%, 30 \%)$ 


\section{Growth rates}

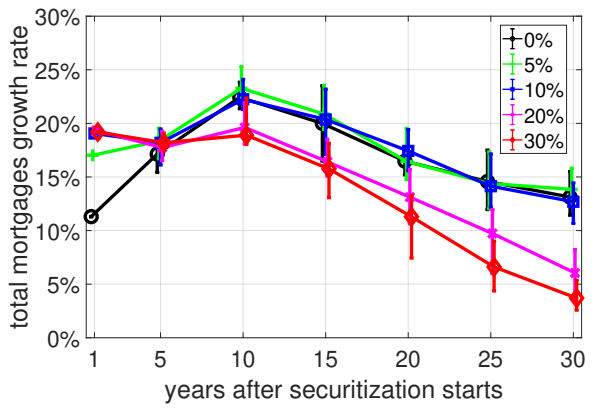

(a)

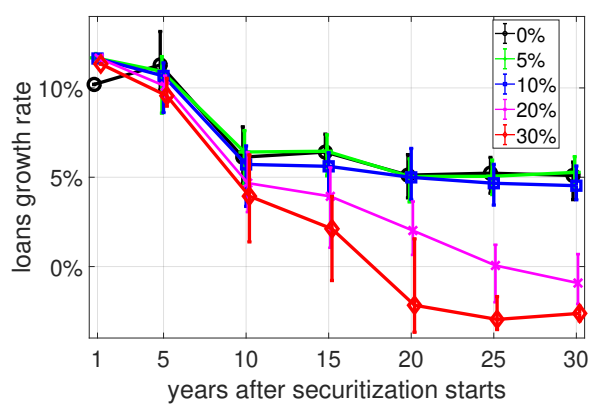

(c)

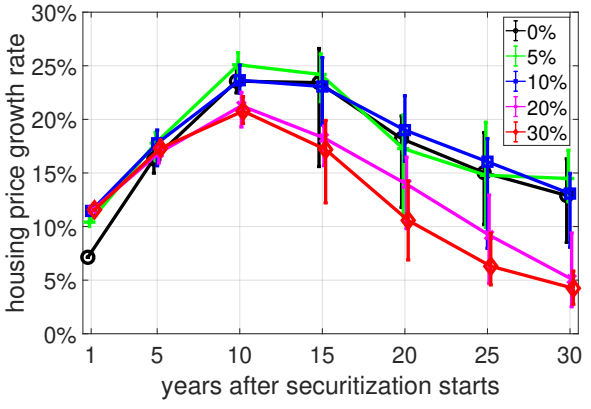

(b)

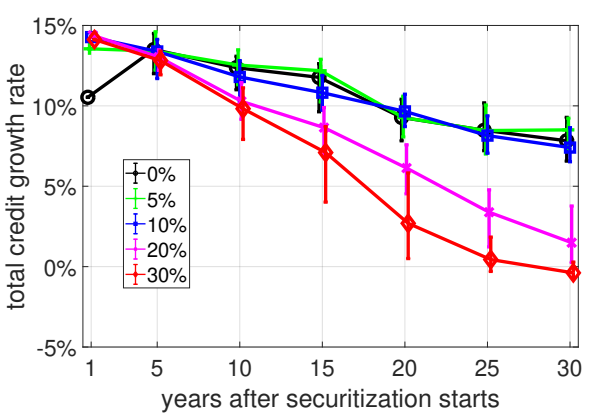

(d)

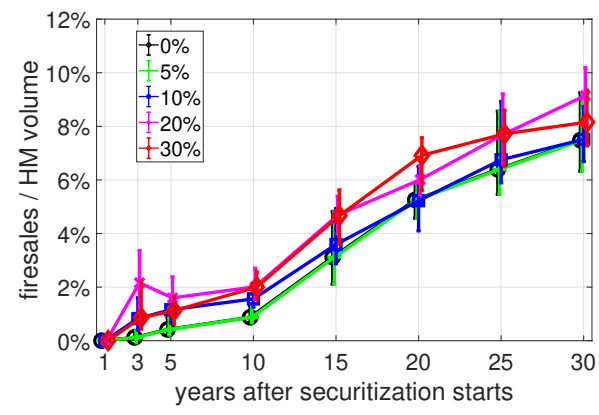

(e)

Figure 6: Growth rate's median, first quartile and third quartile over 50 seeds of credit and housing price. Growth rates are computed as the percentage increase of the selected variable in certain years (each of them reported in the x-axis) with respect to its value in year 5 . Five securitisation propensity values $(\mu)$ are considered $(0 \%, 5 \%, 10 \%, 20 \%, 30 \%)$ 


\section{Firms' data}

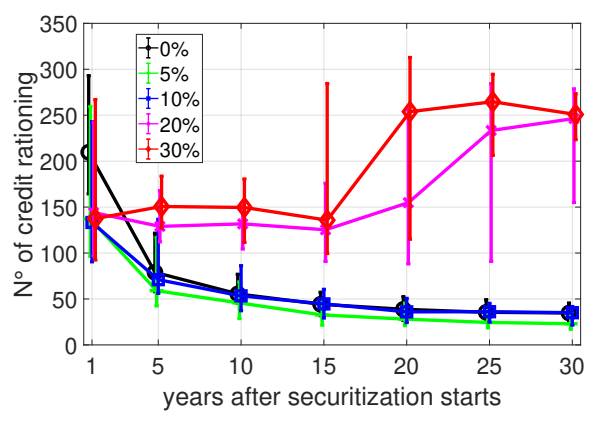

(a)

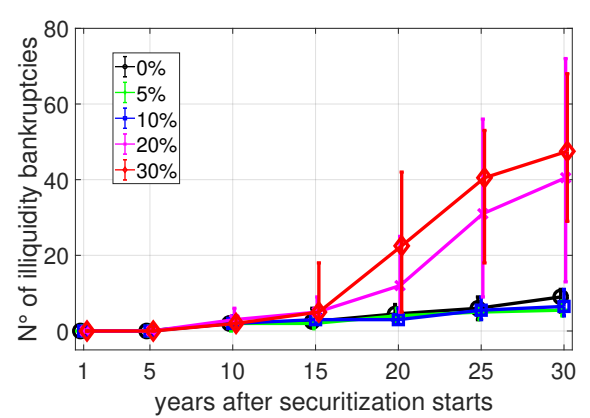

(b)

Figure 7: Yearly mean's median, first quartile and third quartile over 50 seeds of a set of firms' data. Yearly means are computed across different time windows, each of them reported in the x-axis. Five securitisation propensity values $(\mu)$ are considered $(0 \%, 5 \%, 10 \%, 20 \%, 30 \%)$

negative, the government provides the banks with the liquidity necessary to exceed the regulatory capital requirement and carry on lending activity. However, bailout costs are paid by the government (panel (c) in figure 8), increasing its expenses (panel (a) in figure 8) and deficit to GDP ratio (panel (b) in figure 8). In a Stability and growth pact scenario ${ }^{15}$, this leads to an increase of taxes, de facto offloading the costs of bailout on taxpayers (panel (d) in figure 8).

\subsection{Securitisation and macroeconomic variables}

By affecting the credit and the housing market, securitisation also impacts the main macroeconomic indicators. Figure 9 shows real consumption (panel (a)) and unemployment rate (panel (b)). In the short and medium run the securitisation process allows banks to grant more credit (figures 5), triggering also an expansionary effect on consumption (in relative terms, comparing the different values of $\mu$ ) and a consequent reduction of the unemployment rate. However, in the longer run, expecially for scenarios with $\mu=20 \%$ and $30 \%$, the higher instability of the banking system, subsidized by taxpayers by means of recessive fiscal policies, leads to higher levels of unemployment.

\subsection{Systemic risks indicators}

Figure 10 presents the time evolution of five systemic risk indicators, which are potential candidates to be used as early warnings for incoming financial crises. As the focus of the paper is on the banking system and credit market, we examined indicators that mainly target banks' assets. In particular, we distinguish two types of indicators, a first one, reported in figures 10a and 10c, which considers only assets in the balance sheet of the bank, and a second one, reported in figures 10b, 10d and 10e, which includes also off-balance sheet assets.

\footnotetext{
${ }^{15}$ In the current framework, the fiscal policy is ruled by a Stability and Growth Pact scenario (SGP), where government target a deficit to GDP ratio of $3 \%$, by adjusting the tax rates ((see Teglio et al., 2017) for details)
} 


\section{Government data}

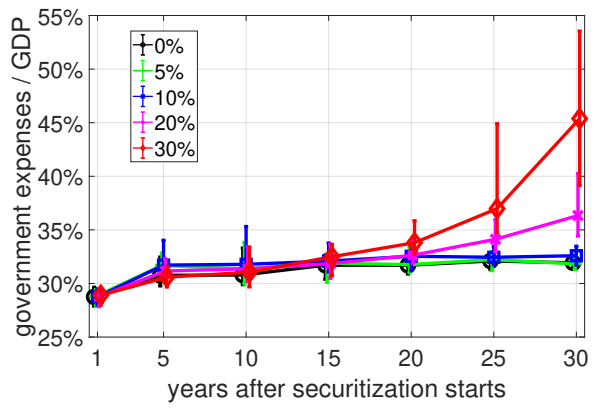

(a)

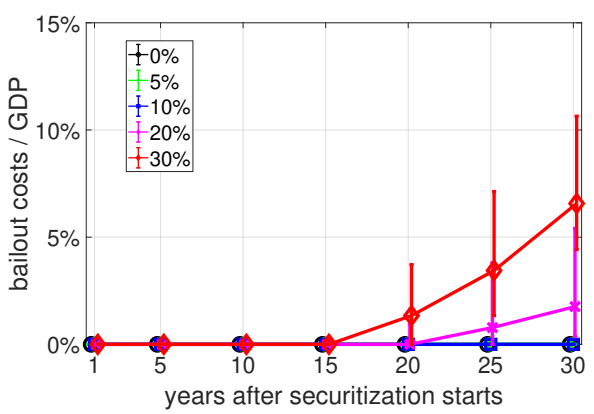

(c)

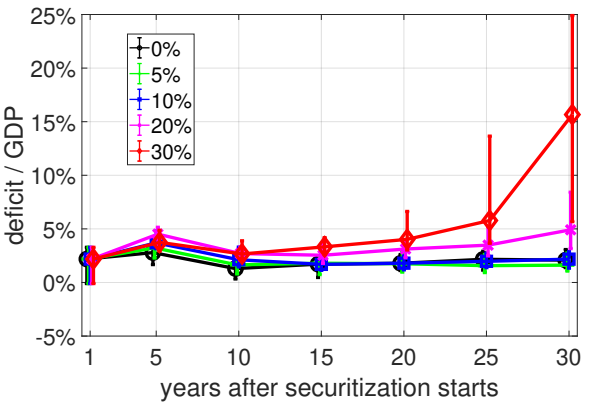

(b)

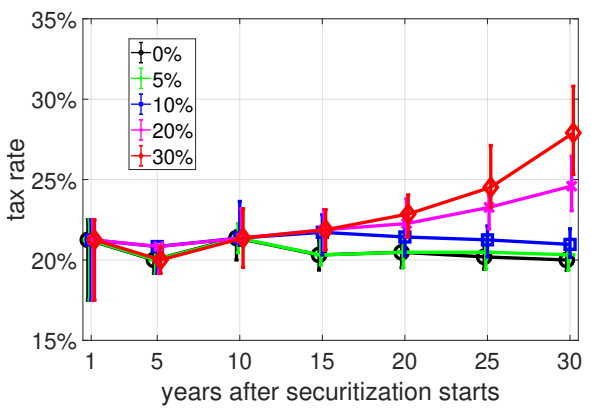

(d)

Figure 8: Yearly mean's median, first quartile and third quartile over 50 seeds of a set of government data. Yearly means are computed across different time windows, each of them reported in the x-axis. Five securitisation propensity values $(\mu)$ are considered $(0 \%, 5 \%, 10 \%, 20 \%, 30 \%)$

\section{Macroeconomic data}

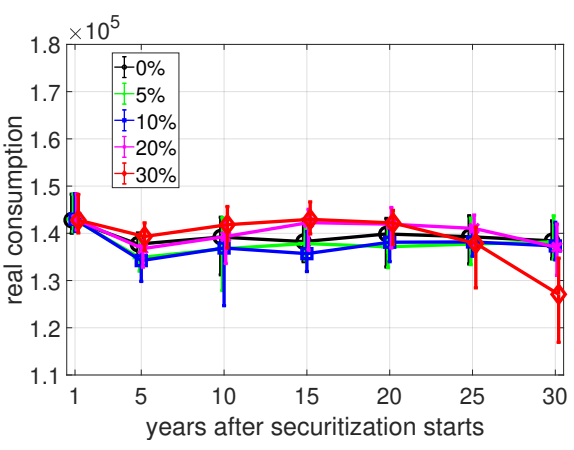

(a)

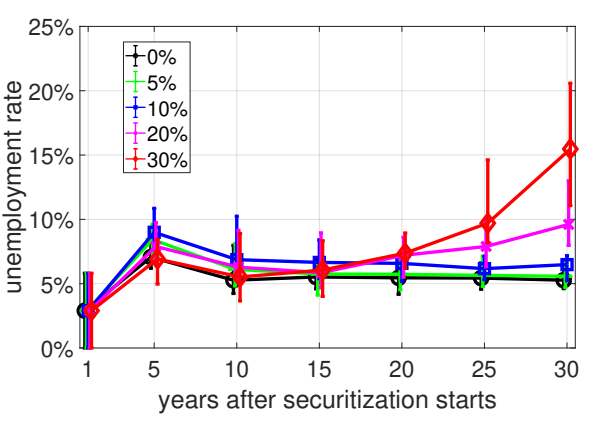

(b)

Figure 9: Yearly mean's median, first quartile and third quartile over 50 seeds of a set of macroeconomic output. Yearly means are computed across different time windows, each of them reported in the x-axis. Five securitisation propensity values $(\mu)$ are considered $(0 \%, 5 \%, 10 \%, 20 \%, 30 \%)$ 
The indicators in the upper row (figures 10a and 10b) represent bank leverage, computed as the ratio between bank's weighted assets and equity. The indicators in the middle row (figures 10c and 10d) focus on the ratio between mortgages and GDP, while the last indicator (figure 10e) focuses specifically on the off-balance sheet assets, as explained in section 4 .

We remind here that the capital requirements for banks are set to $10 \%$, therefore allowing for a maximum leverage of 10. Indeed, banks are able to comply with a leverage value under 10 until year 15, as figure 10a shows, while afterwards the leverage tends to increase in the case of higher securitization propensity, as banks are not stockpiling enough capital buffer. The leverage measure increases when also off-balance assets are considered, as in figure 10b, supposedly revealing a higher systemic risk in the economy.

In a similar way, figure 10d shows the mortages to GDP ratio when also off-balance mortgages are considered. However, in this case, differently from the previous one, the risk indicator in the high securitisation scenarios are lower. Therefore this indicator does not warn about a higher risk when securitisation is active.

The last indicator, in figure 10e, which targets directly the off-balance sheets assets, weighted by the economic activity (GDP), reveals, on the other hand, a strong risk in the case of high securitisation scenarios.

We assess the effectiveness of the different risk indicators in predicting economic and financial crises by examining the cross-correlation of the indicators with the number of total bankruptcies, used as a proxy for the crisis. Tables from 1 to 5 report these cross-correlations, considered with negative lags up to four years, even if we are mainly interested to examine the minus one lag, i.e., the correlation of total bankruptcies with the risk indicator one year before.

In principle, a good indicator should have a high correlation value for all the different scenarios, as the securitisation propensity is not directly observable in the real world. In general, indicators including off-BS assets have a better performance, while the ones excluding them could be completely misleading as in the case of table 3 , where the cross-correlation at $t-1$ is even negative. In particular, the total mortgage to GDP indicator and the VUC indicator show both a positive and consistent correlation between the number of bankruptcies and the value of the indicators in the previous years. However, the values of the correlation coefficients are not extremely high and it is not easy to identify a clear "alarm" threshold, beyond which the economy should be considered at danger.

In tables 6 and 7 we use fire-sales in the housing market as an alternative indicator for measuring the magnitude of the crisis. Results show again that it is essential to consider indicators with off-BS assets in the high securitisation scenarios. Moreover the correlation between the mortgage to GDP indicator with successive crises (measured as fire-sales amount) is stronger. This can be explained by the fact that borrowers of mortgage loans are the first "victims" of an extra leveraged credit market, and therefore the effect on firesales is stronger. The effect on firms' bankruptcies is still there, but it is attenuated by a longer economic transmission chain of the credit shock. 


\section{Systemic risk indicators}

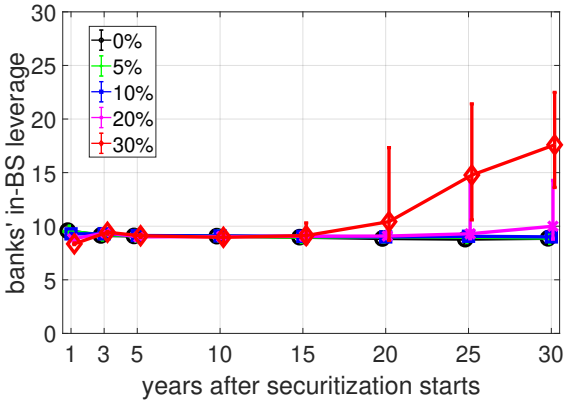

(a)

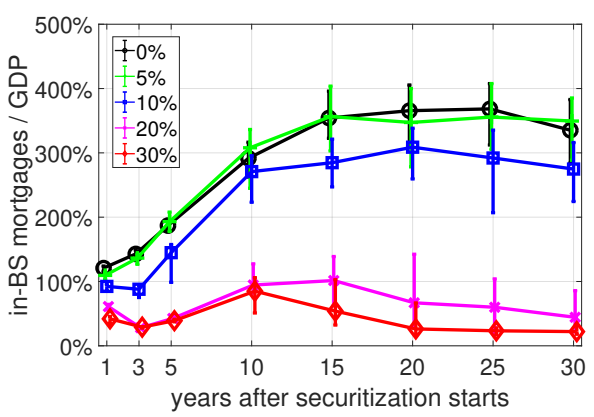

(c)

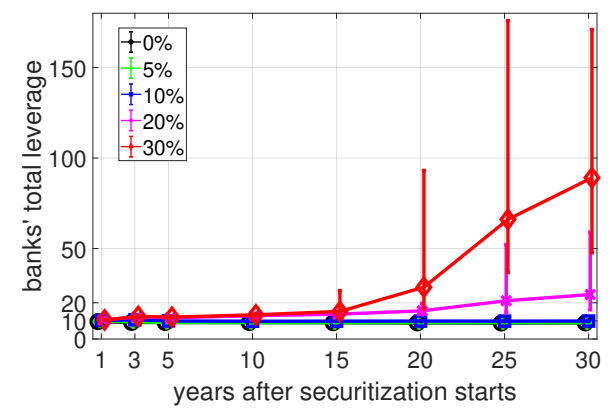

(b)

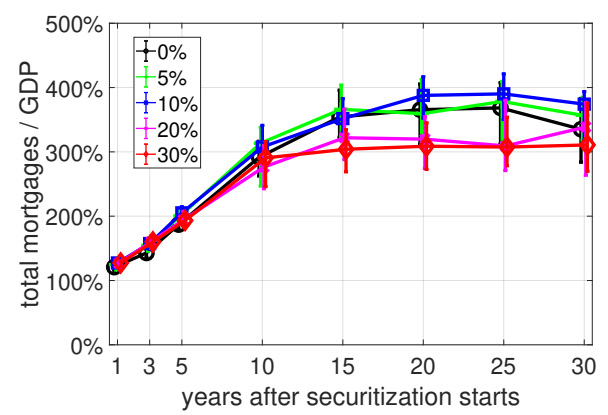

(d)

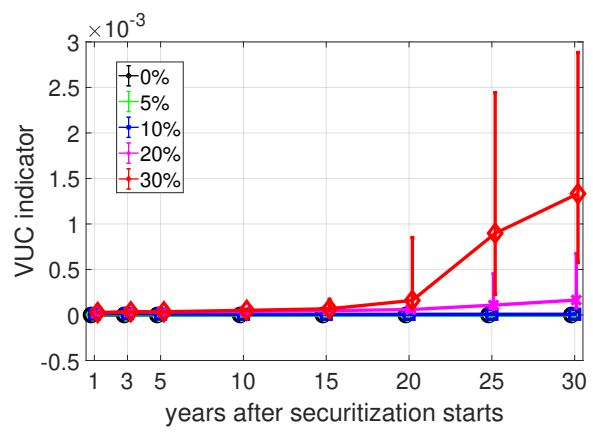

(e)

Figure 10: Yearly value's median, first quartile and third quartile over 50 seeds of systemic risk indicators. Yearly values are computed by considering each indicator in certain years (each of them reported in the x-axis). Five securitisation propensity values $(\mu)$ are considered $(0 \%, 5 \%, 10 \%, 20 \%, 30 \%)$ 


\section{Crosscorrelations}

\begin{tabular}{rrrrrr}
\hline$\mu$ & $\mathrm{t}-4$ & $\mathrm{t}-3$ & $\mathrm{t}-2$ & $\mathrm{t}-1$ & $\mathrm{t}$ \\
\hline $0 \%$ & $-0.07(0.01)$ & $-0.20(0.02)$ & $-0.31(0.02)$ & $-0.06(0.02)$ & $0.28(0.01)$ \\
$10 \%$ & $-0.04(0.01)$ & $-0.08(0.01)$ & $-0.10(0.01)$ & $0.01(0.01)$ & $0.26(0.01)$ \\
$20 \%$ & $0.13(0.03)$ & $0.14(0.04)$ & $0.12(0.04)$ & $0.19(0.03)$ & $0.28(0.03)$ \\
$30 \%$ & $0.23(0.04)$ & $0.25(0.04)$ & $0.22(0.04)$ & $0.22(0.04)$ & $0.19(0.03)$ \\
\hline
\end{tabular}

Table 1: Cross-correlation of regulatory leverage (banks' equity to in-BS weighted assets ratio) and total bankruptcies. Standard errors in parentheses

\begin{tabular}{rrrrrr}
\hline$\mu$ & $\mathrm{t}-4$ & $\mathrm{t}-3$ & $\mathrm{t}-2$ & $\mathrm{t}-1$ & $\mathrm{t}$ \\
\hline $0 \%$ & $-0.07(0.01)$ & $-0.20(0.02)$ & $-0.31(0.02)$ & $-0.06(0.02)$ & $0.28(0.01)$ \\
$10 \%$ & $-0.05(0.01)$ & $-0.08(0.01)$ & $-0.05(0.01)$ & $0.21(0.01)$ & $0.40(0.02)$ \\
$20 \%$ & $0.23(0.03)$ & $0.26(0.03)$ & $0.27(0.04)$ & $0.34(0.03)$ & $0.35(0.03)$ \\
$30 \%$ & $0.33(0.03)$ & $0.36(0.04)$ & $0.31(0.03)$ & $0.29(0.03)$ & $0.18(0.03)$ \\
\hline
\end{tabular}

Table 2: Cross-correlation of total leverage (banks' equity to total weighted assets ratio) and total bankruptcies. Standard errors in parentheses

\begin{tabular}{rrrrrr}
\hline$\mu$ & $\mathrm{t}-4$ & $\mathrm{t}-3$ & $\mathrm{t}-2$ & $\mathrm{t}-1$ & $\mathrm{t}$ \\
\hline $0 \%$ & $0.19(0.02)$ & $0.18(0.02)$ & $0.21(0.02)$ & $0.23(0.02)$ & $0.28(0.02)$ \\
$10 \%$ & $0.19(0.02)$ & $0.21(0.02)$ & $0.18(0.02)$ & $0.05(0.02)$ & $0.04(0.02)$ \\
$20 \%$ & $0.01(0.03)$ & $0.02(0.03)$ & $-0.02(0.03)$ & $-0.20(0.03)$ & $-0.27(0.02)$ \\
$30 \%$ & $-0.09(0.02)$ & $-0.11(0.03)$ & $-0.14(0.02)$ & $-0.24(0.02)$ & $-0.26(0.02)$ \\
\hline
\end{tabular}

Table 3: Cross-correlation of in-BS mortgages to GDP ratio and total bankruptcies. Standard errors in parentheses

\begin{tabular}{rrrrrr}
\hline$\mu$ & $\mathrm{t}-4$ & $\mathrm{t}-3$ & $\mathrm{t}-2$ & $\mathrm{t}-1$ & $\mathrm{t}$ \\
\hline $0 \%$ & $0.19(0.02)$ & $0.18(0.02)$ & $0.21(0.02)$ & $0.23(0.02)$ & $0.28(0.02)$ \\
$10 \%$ & $0.14(0.01)$ & $0.17(0.02)$ & $0.17(0.02)$ & $0.19(0.02)$ & $0.24(0.02)$ \\
$20 \%$ & $0.15(0.02)$ & $0.18(0.02)$ & $0.19(0.02)$ & $0.23(0.02)$ & $0.25(0.02)$ \\
$30 \%$ & $0.16(0.01)$ & $0.18(0.01)$ & $0.18(0.02)$ & $0.24(0.02)$ & $0.27(0.02)$ \\
\hline
\end{tabular}

Table 4: Cross-correlation of total mortgages to GDP ratio and total bankruptcies. Standard errors in parentheses

\begin{tabular}{rrrrrr}
\hline$\mu$ & $\mathrm{t}-4$ & $\mathrm{t}-3$ & $\mathrm{t}-2$ & $\mathrm{t}-1$ & $\mathrm{t}$ \\
\hline $0 \%$ & & & & & \\
$10 \%$ & $-0.08(0.02)$ & $-0.07(0.02)$ & $0.03(0.02)$ & $0.43(0.02)$ & $0.48(0.02)$ \\
$20 \%$ & $0.24(0.03)$ & $0.26(0.03)$ & $0.26(0.03)$ & $0.35(0.03)$ & $0.30(0.03)$ \\
$30 \%$ & $0.27(0.03)$ & $0.28(0.03)$ & $0.22(0.03)$ & $0.22(0.03)$ & $0.12(0.03)$ \\
\hline
\end{tabular}

Table 5: Cross-correlation of VUC indicator and total bankruptcies. Standard errors in parentheses

\begin{tabular}{rrrrrr}
\hline$\mu$ & $\mathrm{t}-4$ & $\mathrm{t}-3$ & $\mathrm{t}-2$ & $\mathrm{t}-1$ & $\mathrm{t}$ \\
\hline $0 \%$ & $0.23(0.02)$ & $0.27(0.01)$ & $0.41(0.01)$ & $0.47(0.01)$ & $0.60(0.01)$ \\
$10 \%$ & $0.23(0.02)$ & $0.25(0.02)$ & $0.34(0.02)$ & $0.36(0.01)$ & $0.51(0.01)$ \\
$20 \%$ & $0.07(0.03)$ & $0.07(0.03)$ & $0.13(0.03)$ & $0.05(0.03)$ & $0.09(0.03)$ \\
$30 \%$ & $-0.06(0.02)$ & $-0.07(0.02)$ & $-0.03(0.02)$ & $-0.08(0.02)$ & $0.01(0.03)$ \\
\hline
\end{tabular}

Table 6: Cross-correlation of in-BS mortgages to GDP and firesales. Standard errors in parentheses 


\begin{tabular}{rrrrrr}
\hline$\mu$ & $\mathrm{t}-4$ & $\mathrm{t}-3$ & $\mathrm{t}-2$ & $\mathrm{t}-1$ & $\mathrm{t}$ \\
\hline $0 \%$ & $0.23(0.01)$ & $0.27(0.01)$ & $0.41(0.01)$ & $0.47(0.01)$ & $0.60(0.01)$ \\
$10 \%$ & $0.26(0.01)$ & $0.30(0.01)$ & $0.42(0.01)$ & $0.43(0.01)$ & $0.59(0.01)$ \\
$20 \%$ & $0.24(0.01)$ & $0.24(0.01)$ & $0.38(0.01)$ & $0.27(0.01)$ & $0.51(0.01)$ \\
$30 \%$ & $0.24(0.01)$ & $0.23(0.01)$ & $0.37(0.01)$ & $0.26(0.01)$ & $0.47(0.01)$ \\
\hline
\end{tabular}

Table 7: Cross-correlation of total mortgages to GDP and firesales. Standard errors in parentheses 


\section{Conclusions}

The paper studies the effects of the securitisation process in the assessment of systemic financial risk indicators, using the agent-based model Eurace, which includes a housing market in the style of Ozel et al. (2016), and implements a securitisation mechanism on the footprints of Mazzocchetti et al. (2018) and Lauretta (2018) that allows banks to free up their balance sheets from risk-weighted assets and circumvent the prudential capital requirements. The model has been enriched with an endogenous demand specification of mutual fund equity shares and with a bailout resolution mechanism, which foresees the banks' rescue by means of government spending if banks' equity becomes negative.

We analyse the impact of securitisation on credit market and on real economy, finding that scenarions with higher securitisation propensities weaken the financial stability of banks with relevant effects on different sectors of the economy. Moreover, a set of five systemic financial risk indicators is considered: banks' leverage, i.e the ratio between banks' weighted assets and equity, computed using only in-BS weighted assets and total weighted assets; mortgage to GDP ratio, computed using only in-BS mortgages and total mortgages; a fifth indicator, the so-called VUC indicator, which is given by the ratio between off-balance sheet credit and banks' equity, normalized with the GDP.

The results presented in the paper brings clear evidence of the role played by the securitisation process, above certain levels of securitisation propensity, in paving the way toward booms and busts and ensuing economic recessions. Furthermore, the analysis shows how banks can satisfy their capital requirements while contributing to gradually building up higher risk exposure of the whole financial system.

The outcome of the computational experiments show that while the mortgage-to-GDP and banks' leverage can be misleading when considering only in-BS assets, thus not detecting correctly the financial imbalances, the adjusted version of those indicators together with the VUC indicator instead seem more adequate to monitor and anticipate this risk exposure.

Therefore, the paper highlights the importance of considering off-BS items when assessing for systemic risk. However, we remain of the opinion that this does not mean to downgrade the systemic risk indicators based on in-BS items, but their analysis and interpretation for regulatory reasons should be integrated the off-BS items, which play a relevant role in detecting systemic risk, as our results shows. The ABM framework allows to analyse, through numerical simulations, the relevance of off-balance assets in assessing systemic financial risk. Otherwise, this would be more complicated to verify empirically, given the lack of data availability on banks' off-BS assets. Only recently, the European Central Bank has started to gather from the Special Purpose Vehicle/Entity (SPV/SPE) these kind of data for the Euro area.

The data are available from 2012 annually and only from 2014 are they provided quarterly. Future work needs to be done in this direction, and our analysis contributes to highlight as a priority for regulation the access to the off-BS assets data. Of course, other variables can play an important role in developing systemic risk, such as, among others, the size of financial institutions and the exposure in interbank lending. Future research may consider the extension of the present work by developing indicators which compute not only the 
in-BS and off-BS dimensions, but incorporate also other possible relevant variables for monitoirng systemic financial risk. 


\section{Acknowledgment}

The authors acknowledge EU-FP7 collaborative project SYMPHONY ${ }^{16}$ under grant no. 611875.

${ }^{16}$ www.projectsymphony.eu 


\section{References}

Acharya, V. V., Pedersen, L. H., Philippon, T., Richardson, M., 2017. Measuring systemic risk. The Review of Financial Studies 30 (1), 2-47.

Adrian, T., Brunnermeier, M. K., 2016. Covar. American Economic Review 106 (7), 1705-1741.

Bandt, O., Hartmann, P., Peydró, J., 2012. Systemic Risk in Banking: An Update. Oxford University Press, Oxford.

Banulescu, G., Dumitrescu, E., 2015. Which are the SIFIs? a component expected shortfall approach to systemic risk. Journal of Banking and Finance 50, 575-588.

Barrell, R., Davis, E., Karim, D., Liadze, I., 2010. Bank regulation, property prices and early warning systems for banking crises in OECD countries. Journal of Banking \& Finance 34, 2255-2264.

Billio, M., Getmansky, M., Lo, A., Pelizzon, L., 2012. Econometric measures of connectedness and systemic risk in the finance and insurance sectors. Journal of Financial Economics 104 (3), 535-559.

BIS, 2017. High-level summary of basel III reforms. Basel Committee on Banking Supervision.

Borio, C., Lowe, P., 2002a. Asset prices, financial and monetary stability: Exploring the nexus. BIS Working Papers 114, Bank for International Settlements.

Borio, C., Lowe, P., 2002b. Securing sustainable price stability: Should credit come back from the wilderness? BIS Working Papers 157, Bank for International Settlements.

Brunnermeier, M. K., Sannikov, Y., 2014. A macroeconomic model with a financial sector. American Economic Review 104 (2), 379-421.

Caiani, A., Godin, A., Caverzasi, E., Gallegati, M., Kinsella, S., Stiglitz, J. E., 2016. Agent based-stock flow consistent macroeconomics: Towards a benchmark model. Journal of Economic Dynamics and Control 69, $375-408$

Cappiello, L., Kadareja, A., Kok, C., Protopapa, M., 2010. Do bank loans and credit standards have an effect on output? A panel approach for the euro area. Working Paper Series 1150, European Central Bank.

Cincotti, S., Raberto, M., Teglio, A., 2010. Credit money and macroeconomic instability in the agent-based model and simulator Eurace. Economics - The Open-Access, Open-Assessment E-Journal 4, 1-32.

Cincotti, S., Raberto, M., Teglio, A., 2012a. The Eurace macroeconomic model and simulator. In: Agentbased Dynamics, Norms, and Corporate Governance. The proceedings of the 16-th World Congress of the International Economic Association. Vol. II. Palgrave. 
Cincotti, S., Raberto, M., Teglio, A., 2012b. Macroprudential policies in an agent-based artificial economy. Revue de l'OFCE 124 (5), 205-234.

Dawid, H., Gemkow, S., Harting, P., van der Hoog, S., Neugart, M., 2018. Agent-Based Macroeconomic Modeling and Policy Analysis: The Eurace@Unibi Model. Oxford University Press, pp. 490-519.

Deghi, A., Welz, P., Żochowski, D., 2018. A new financial stability risk index to predict the near-term risk of recession. Financial Stability Review.

Delli Gatti, D., Desiderio, S., 2015. Monetary policy experiments in an agent-based model with financial frictions. Journal of Economic Interaction and Coordination 10 (2), 265-286.

Diebold, F., Yilmaz, K., 2014. On the network topology of variance decompositions: measuring the connectedness of financial firms. Journal of Econometrics 182 (1), 119-134.

Dosi, G., Napoletano, M., Roventini, A., Treibich, T., 2017. Micro and macro policies in the Keynes+Schumpeter evolutionary models. Journal of Evolutionary Economics 27 (1), 63-90.

Drehmann, M., Juselius, M., 2014. Evaluating early warning indicators of banking crises: satisfying policy requirements. International Journal of Forecasting 30 (3), 759-780.

ECB, 2009. The concept of systemic risk. Financial Stability Review.

ECB, 2011. Systemic risk methodologies. Financial Stability Review.

Fagiolo, G., Roventini, A., 2017. Macroeconomic policy in DSGE and agent-based models redux: new developments and challenges ahead. Journal of Artificial Societies and Social Simulation, 20 (1), 1.

Gerhardt, M., Vennet, R. V., 2017. Bank bailouts in Europe and bank performance. Finance Research Letters $22,74-80$.

Godley, W., Lavoie, M., 2012. Monetary Economics: An Integrated Approach to Credit, Money, Income, Production and Wealth, 2nd Edition. Palgrave Macmillan: Basingstoke.

Goodhart, C., Segoviano, M., 2009. Banking stability measures. FMG discussion papers, Financial Markets Group.

Gray, D. F., Merton, R. C., Bodie, Z., 2008. New framework for measuring and managing macrofinancial risk and financial stability. Harvard Business School Working Paper 09-015, Levy Economics Institute.

Guerini, M., Lamperti, F., Mazzocchetti, A., 2018. Unconventional monetary policy: between the past and future of monetary economics. European Journal of Economics and Economic Policies 15 (2), 122 - 131.

Huang, X., Zhou, H., Zhu, H., 2009. A framework for assessing the systemic risk of major financial institutions. Journal of Banking and Finance 33 (11), 2036-2049. 
Huang, X., Zhou, H., Zhu, H., 2012. Systemic risk contributions. Journal of Financial Services Research $42(1), 55-83$.

Kinsella, S., Greiff, M., Nell, E. J., 2011. Income distribution in a stock-flow consistent model with education and technological change. Eastern Economic Journal, 37 (1), 134-149.

Lauretta, E., 2018. The hidden soul of financial innovation: An agent-based modelling of home mortgage securitization and the finance-growth nexus. Economic Modelling, 68, 51-73.

Lauretta, E., Chaudhry, S. M., Mullineux, A. W., 2016. Theory and evidence on the finance-growth relationship: The virtuous and unvirtuous cycles. Discussion Paper 2016-8, University of Birmingham, Financial Resilience Research Cluster.

Lehar, A., 2005. Measuring systemic risk: A risk management approach. Journal of Banking \& Finance 29 (10), 2577-2603.

Mazzocchetti, A., Raberto, M., Teglio, A., Cincotti, S., 2018. Securitisation and business cycle: An agentbased perspective. Industrial and Corporate Change (in press).

Misina, M., Tkacz, G., 2009. Credit, asset prices, and financial stress. International Journal of Central Banking, 5 (4), 95-122.

Napoletano, M., Roventini, A., Sapio, S., 2006. Are business cycles all alike? A bandpass filter analysis of the italian and US cycles. Rivista italiana degli economisti, 1/2006, 87-118.

Ozel, B., Nathanael, R. C., Raberto, M., Teglio, A., Cincotti, S., 2016. Macroeconomic implications of mortgage loans requirements: an agent based approach. Working Papers 2016/05, Economics Department, Universitat Jaume I, Castellón (Spain).

Petrovic, M., Ozel, B., Teglio, A., Raberto, M., Cincotti, S., 2017. Eurace open: An agent-based multi-country model. Working Papers 2017/09, Economics Department, Universitat Jaume I, Castellón (Spain).

Ponta, L., Raberto, M., Teglio, A., Cincotti, S., 2018. An agent-based stock-flow consistent model of the sustainable transition in the energy sector. Ecological Economics 145, 274-300.

Raberto, M., Teglio, A., Cincotti, S., 2012. Debt deleveraging and business cycles. an agent-based persperctive. The Open-Access, Open-Assessment E-Journal, 6, 2012-27.

Riccetti, L., Russo, A., Gallegati, M., 2015. An agent based decentralized matching macroeconomic model. Journal of Economic Interaction and Coordination, 10 (2), 305-332.

Schwaab, B., Koopman, S. J., Lucas, A., 2011. Systemic risk diagnostics: coincident indicators and early warning signals. Working Paper Series 1327, European Central Bank. 
Teglio, A., Mazzocchetti, A., Ponta, L., Raberto, M., Cincotti, S., 2017. Budgetary rigour with stimulus in lean times: Policy advices from an agent-based model. Journal of Economic Behavior and Organization (in press).

Teglio, A., Raberto, M., Cincotti, S., 2010. Balance sheet approach to agent-based computational economics: The Eurace project. In: Combining Soft Computing and Statistical Methods in Data Analysis. Vol. 77 of Advances in Intelligent and Soft Computing. Springer Berlin / Heidelberg, pp. 603-610.

Trichet, J., 2009. Clare distinguished lecture in economics and public policy. University of Cambridge, 10 December 2009.

Uribe, M., Schmitt-Grohé, S., 2017. Open economy macroeconomics. Princeton University Press: Princeton, New Jersey.

Watson, M., Stock, J., 1999. Business Cycle Fluctuations in U.S. Macroeconomic Time Series. Elsevier, Amsterdam, pp. 3-64. 


\section{Appendix}

\subsection{Balance sheet matrices}

In order to provide an exhaustive description of agents' balance sheets and the stock-flow relations among sectors in Eurace, we present a set of four tables. Table 8 shows the asset and liability entries of each particular agent type. Table 9 represents the balance sheet matrix, describing all assets and liabilities for each sector (here a sector has to be seen as a class of agents). In this matrix a plus (minus) sign corresponds to agents assets (liabilities), and each column can be read as the aggregated balance sheet of a specific sector. Rows show assets and claims of assets among sectors, thus generally adding up to 0. Exceptions are capital and inventories, which are accumulated by CGPs, and households equity shares of CGPs and banks that do not add up to 0 because market price and book value can be different. However, being the equity shares of capital good producer (KGP), financial vehicle corporation (FVC), and mutual fund (MF) not traded in the financial market, their market price and book value coincide. Table 10, called transaction flow matrix, shows all the stock and monetary flows among agent classes. The top part, i.e. cash receipts/outlays, describes the flows of revenues (plus sign) and payments (minus sign) that agents get and make. Agents are reported in the columns, and monetary flows are reported in the rows. The result of agents sector transactions is the net cash flow (NCF). The bottom part of Table 10 describes the changes in financial/monetary assets/liabilities

among periods. Finally, table 11, called equity capital change matrix, reports the variation of agents' equity capital between two periods, due to net cash flows, price changes in assets and liabilities, stock changes in real assets, and issues of equity shares. 
Table 8: Agent class balance sheets

\begin{tabular}{|c|c|c|}
\hline Agent class & Assets & Liabilities \\
\hline $\begin{array}{l}\text { Household } \\
\text { abbrev.: } \mathrm{HH} \\
\text { index: } h=1, \ldots, N_{\text {Hous }}\end{array}$ & $\begin{array}{l}\text { Liquidity: } M_{h} \\
\text { Stock portfolio: } \\
\Sigma_{b} n_{E_{h, b}} p_{E_{b}}+ \\
\Sigma_{f} n_{E_{h, f}} p_{E_{f}}+ \\
n_{E_{h, K}} p_{E_{K}}+ \\
n_{E_{h, D}} p_{E_{D}} \\
\text { Gov Bonds: } n_{h, G} p_{G} \\
\text { Housing units: } X_{h}\end{array}$ & $\begin{array}{l}\text { Mortgages: } U_{h} \\
\text { Equity: } E_{h}\end{array}$ \\
\hline $\begin{array}{l}\text { Consumption Goods Pro- } \\
\text { ducer } \\
\text { abbrev: CGP } \\
\text { index: } f=1, \ldots, N_{\text {Firm }}\end{array}$ & $\begin{array}{l}\text { Liquidity: } M_{f} \\
\text { Capital goods: } K_{f} \\
\text { Inventories: } I_{f}\end{array}$ & $\begin{array}{l}\text { Debt: } D_{f}=\sum_{b} \ell_{f, b} \\
\text { Equity: } E_{f}\end{array}$ \\
\hline $\begin{array}{l}\text { Capital Goods Producer } \\
\text { abbrev.: KGP }\end{array}$ & Liquidity: $M_{K}$ & Equity: $E_{K}$ \\
\hline $\begin{array}{l}\text { Financial Vehicle Corpora- } \\
\text { tion } \\
\text { abbrev.: } \mathrm{V}\end{array}$ & $\begin{array}{l}\text { Liquidity: } M_{V} \\
\text { Loans: } \mathcal{L}_{V} \\
\text { Mortgages: } U_{V}\end{array}$ & $\begin{array}{l}\text { Asset backed securities (ABSs): } \\
A B S_{V} \\
\text { Mortgage backed securities } \\
\text { (MBSs): } M B S_{V} \\
\text { Equity: } E_{V}\end{array}$ \\
\hline $\begin{array}{l}\text { Mutual Fund } \\
\text { abbrev.: D }\end{array}$ & $\begin{array}{l}\text { Liquidity: } M_{D} \\
\text { Asset backed securities (ABSs): } \\
A B S_{D} \\
\text { Mortgage backed securities } \\
\text { (MBSs): } M B S_{D}\end{array}$ & Equity: $E_{D}$ \\
\hline $\begin{array}{l}\text { Bank } \\
\text { abbrev.: } \mathrm{B} \\
\text { index: } b=1, \ldots, N_{\text {Bank }}\end{array}$ & $\begin{array}{l}\text { Liquidity: } M_{b} \\
\text { Loans: } \mathcal{L}_{b}=\sum_{f} \ell_{b, f} \\
\text { Mortgages: } U_{b}=\sum_{h} U_{b, h} \\
\text { Stock portfolio: } \\
n_{E_{b, V}} p_{E_{V}}\end{array}$ & $\begin{array}{l}\text { Deposits : } \\
\mathcal{D}_{b}=\sum_{h} M_{b, h}+\sum_{f} M_{b, f}+M_{b, K} \\
\text { CB standing facility: } D_{b}=\ell_{b, C B} \\
\text { Equity: } E_{b}\end{array}$ \\
\hline $\begin{array}{l}\text { Government } \\
\text { abbrev.: G }\end{array}$ & Liquidity: $M_{G}$ & $\begin{array}{l}\text { Outstanding government bonds } \\
\text { value: } D_{G}=n_{G} p_{G} \\
\text { Equity: } E_{G}\end{array}$ \\
\hline $\begin{array}{l}\text { Central Bank } \\
\text { abbrev.: CB }\end{array}$ & $\begin{array}{l}\text { Liquidity: } M_{C B} \\
\text { Loans to banks: } \mathcal{L}_{C B}=\sum_{b} \ell_{C B, b} \\
\text { Gov Bonds: } n_{C B, G} p_{G}\end{array}$ & $\begin{array}{l}\text { Outstanding fiat money: } \text { Fiat }_{C B} \\
\text { Deposits: } \mathcal{D}_{C B}=\sum_{b} M_{b}+M_{G} \\
\text { Equity: } E_{C B}\end{array}$ \\
\hline
\end{tabular}

Balance sheets of any agent class characterizing the Eurace economy. Balance sheet entries in the table have a subscript character, that is the index of an agent in the class to which the variable refers. In some cases, we can find two subscript characters, where the second one refers to the index of an agent in another class where there is the balance-sheet counterpart. For instance, $D_{f}$ refers to the total debt of firm $f$, i.e. a liability, and $\mathcal{L}_{b}$ refers to the aggregate loans of bank $b$, i.e. an asset. $\ell_{f, b}\left(\right.$ or $\ell_{b, f}$ ) refer to the loans granted by banks $b$ to firms $f$. Of course, $\sum_{b} \mathcal{L}_{b}=\sum_{f} \ell_{b, f}$ represents an aggregate balance sheet identity, that is verified along the entire simulation. $n_{E_{h, x}}$ represent the number of outstanding equity shares of agents $x$ held by households $h$. The market price of the equity shares is given by $p_{E_{x}}$. The stock portfolio's value of household $h$ is then computed as: $\sum_{x} n_{E_{h, x}} p_{E_{x}}$. Government bonds' number and market price are given by $n_{G}$ and $p_{G}$, respectively. 


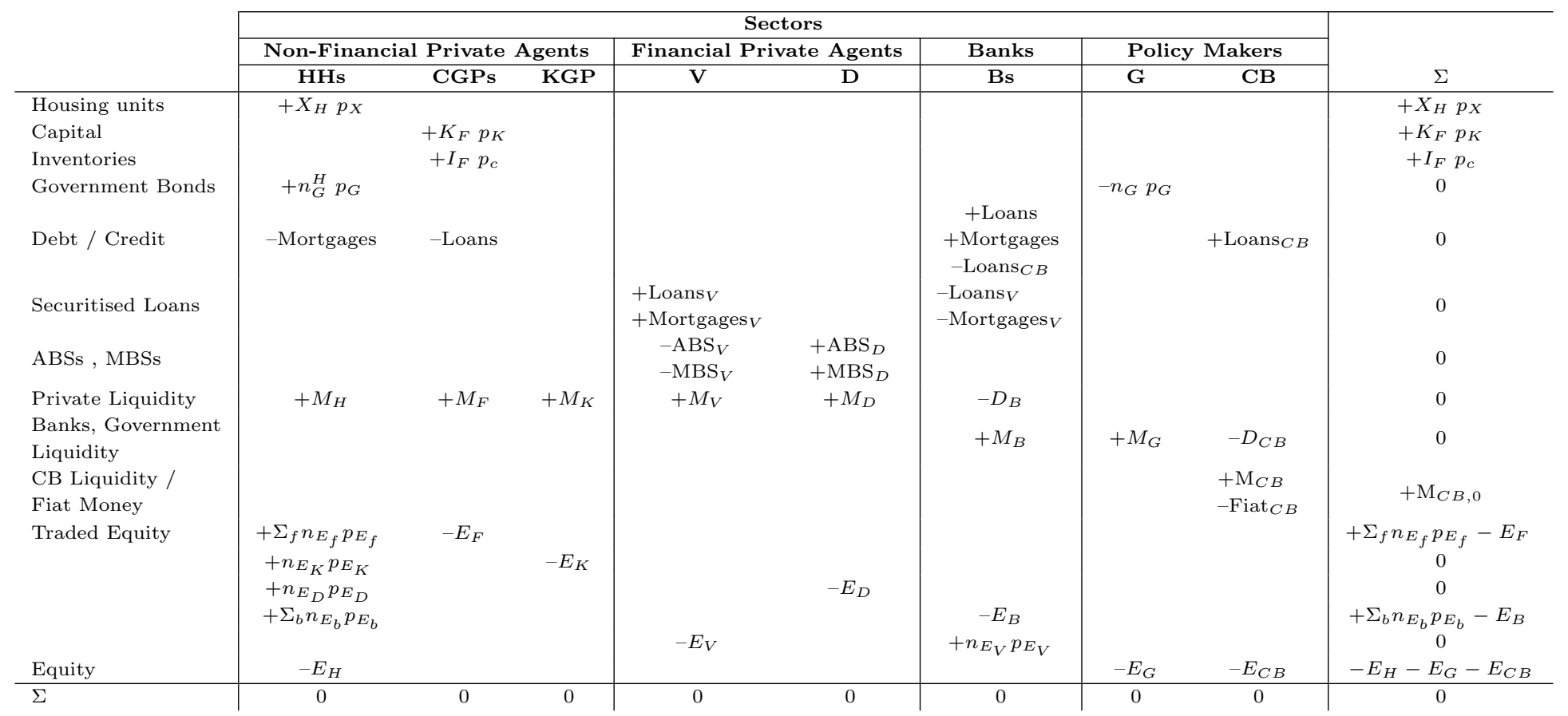

Table 9: Sectorial balance sheet matrix. Subscripts represent the index of the agent to which the stock refers. Uppercase subscripts are used when the stock refers to a whole sector, whereas lowercase subscripts are used when it refers to a single agent (for instance in the case of sums). Finally, superscript characters are introduced when the balance sheet counterpart is more than one single sector. 


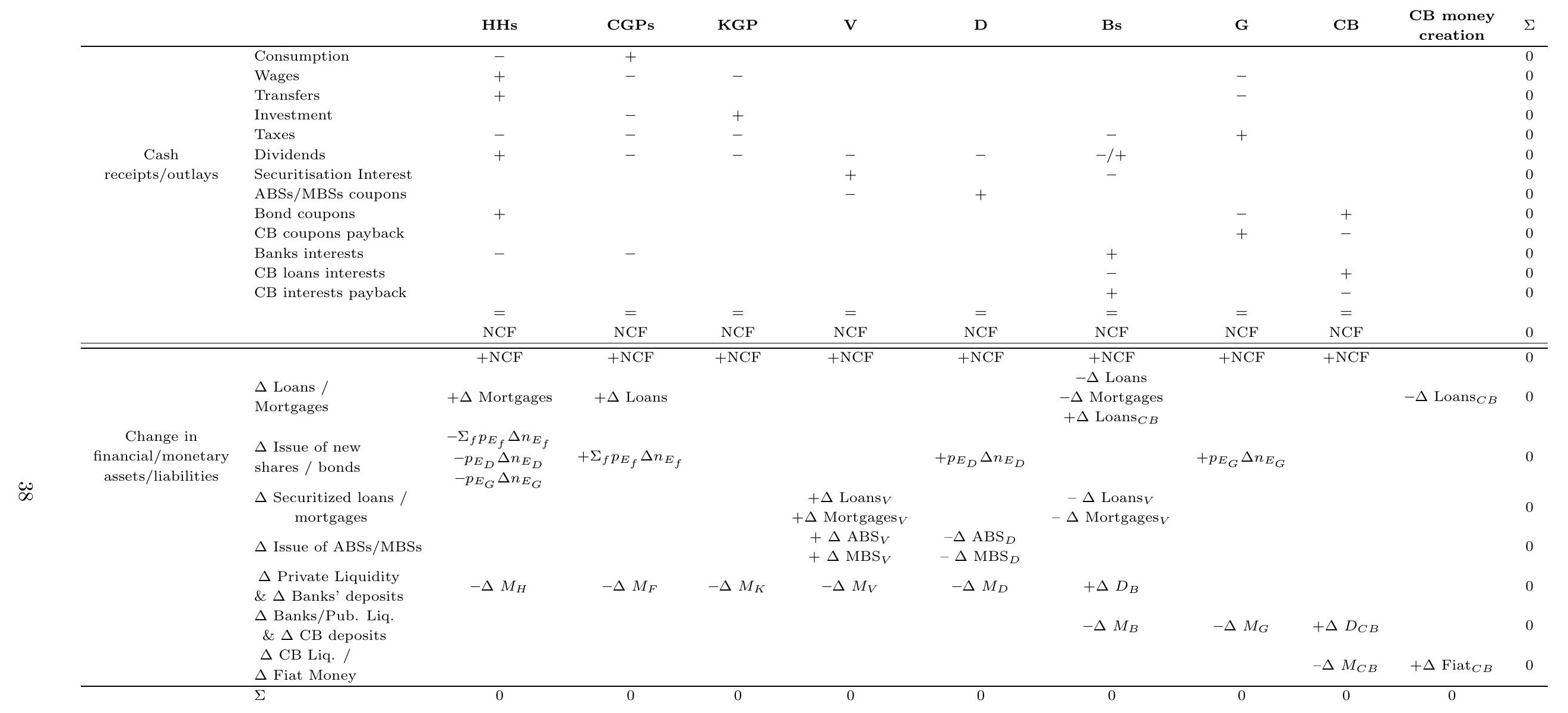

Table 10: Sectorial transaction flow matrix of agents populating the EURACE economy 


\begin{tabular}{|c|c|c|c|c|c|c|c|c|c|c|}
\hline & & HHs & CGPs & KGP & $\mathrm{v}$ & $\mathrm{D}$ & Bs & $\mathrm{G}$ & $\mathrm{CB}$ & $\Sigma$ \\
\hline Equity $_{t-1}$ & & $\frac{E_{H, t-1}}{+\mathrm{NCF}}$ & $\frac{E_{F, t-1}}{+\mathrm{NCF}}$ & $\frac{E_{K, t-1}}{+\mathrm{NCF}}$ & $\frac{E_{V, t-1}}{+ \text { NCF }}$ & $\frac{E_{D, t-1}}{+\mathrm{NCF}}$ & $\frac{E_{B, t-1}}{+ \text { NCF }}$ & $\frac{E_{G, t-1}}{+\mathrm{NCF}}$ & $\frac{E_{C B, t-1}}{+\mathrm{NCF}}$ & $\frac{E_{T O T, t-1}}{0}$ \\
\hline \multicolumn{11}{|l|}{$\begin{array}{l}\text { Price change in } \\
\text { assets/liabilities }\end{array}$} \\
\hline & $\begin{array}{l}\text { Housing units } \\
\text { Tangible Capital } \\
\text { Inventories }\end{array}$ & $+\Sigma_{h} \Delta p_{X} X_{h}$ & $\begin{array}{l}+\Sigma_{f} \Delta p_{K} K_{f} \\
+\Sigma_{f} \Delta p_{c} I_{f}\end{array}$ & & & & & & & $\begin{array}{l}+\Sigma_{h} \Delta p_{X} X_{h} \\
+\Sigma_{f} \Delta p_{K} K_{f} \\
+\Sigma_{f} \Delta p_{c} I_{f}\end{array}$ \\
\hline & $\begin{array}{l}\text { Equity shares } \\
\text { Bonds }\end{array}$ & $\begin{array}{l}+\Sigma_{f} \Delta p_{E_{f}} n_{E_{f}} \\
+\Sigma_{b} \Delta p_{E_{b}} n_{E_{b}} \\
\quad+\Delta p_{G} n_{G}\end{array}$ & & & & & & $-\Delta p_{C} n_{C}$ & & $\begin{array}{c}+\Sigma_{f} \Delta p_{E_{f}} n_{E_{f}} \\
+\Sigma_{b} \Delta p_{E_{b}} n_{E_{b}} \\
0\end{array}$ \\
\hline \multicolumn{11}{|l|}{$\begin{array}{l}\text { Stock change } \\
\text { in real assets }\end{array}$} \\
\hline & $\begin{array}{l}\text { Tangible Capital } \\
\text { Inventories }\end{array}$ & & $\begin{array}{c}+\Sigma_{f} p_{K} \Delta K_{f} \\
+\Sigma_{f} p_{c} \Delta I_{f}\end{array}$ & & & & & & & $\begin{array}{l}+\Sigma_{f} p_{K} \Delta K_{f} \\
+\Sigma_{f} p_{c} \Delta I_{f}\end{array}$ \\
\hline \multicolumn{11}{|l|}{$\begin{array}{l}\text { Issues of } \\
\text { equity shares }\end{array}$} \\
\hline & & & $+\Sigma_{f}{ }^{p} E_{f} \Delta n_{E_{f}}$ & & & & & & & $+\Sigma_{f} p_{E_{f}} \Delta n_{E_{f}}$ \\
\hline & & $=$ & $=$ & $=$ & $=$ & 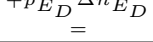 & $=$ & $=$ & $=$ & $\begin{array}{c}{ }^{+P_{E}}{ }_{D}={ }^{\Delta n_{E}} E_{D} \\
=\end{array}$ \\
\hline Equity $t$ & & $E_{H, t}$ & $E_{F, t}$ & $E_{K, t}$ & $E_{V, t}$ & $E_{D, t}$ & $E_{B, t}$ & $E_{G, t}$ & $E_{C B, t}$ & $E_{T O T, t}$ \\
\hline
\end{tabular}

Table 11: Equity capital change matrix. $\Delta K_{f}$ represents the net investment, i.e. the difference between gross investment and capital depreciation. NCF stands for Net Cash Flow. Bank's $b$ equity shares are traded in stock market but banks do not issue equity shares. However, mutual fund's $D$ equity shares are not traded in the financial market but the mutual fund can issue new equity shares. 


\subsection{Stylized facts and validation}

Since in the explanations of computational experiments' results we often refer to the synchronization among different variables during the business cycle, we have performed a cross-correlation analysis, in order to objectively assess the correlation of those variables for different time lags. Figure 11 shows some crosscorrelation figures. We condider monthly HP detrended time series' averages of 50 simultation runs, one for each seed used for the pseudo-random number generator. In figure 11, we show the cross-correlations for 20 positive and negative lags, as well as the upper and lower confidence bounds. We observe that real GDP is positively correlated with consumption and investments, and it is anti-correlated with the unemployment rate. GDP also shows a positive correlation with loans to firms, which are leading the business cycle expansion, while stock and bond prices are anti-correlated. This results are in line with main stylized facts on credit and business cycle (see for instance Watson and Stock (1999), Napoletano et al. (2006), Cappiello et al. (2010) and Uribe and Schmitt-Grohé (2017)).
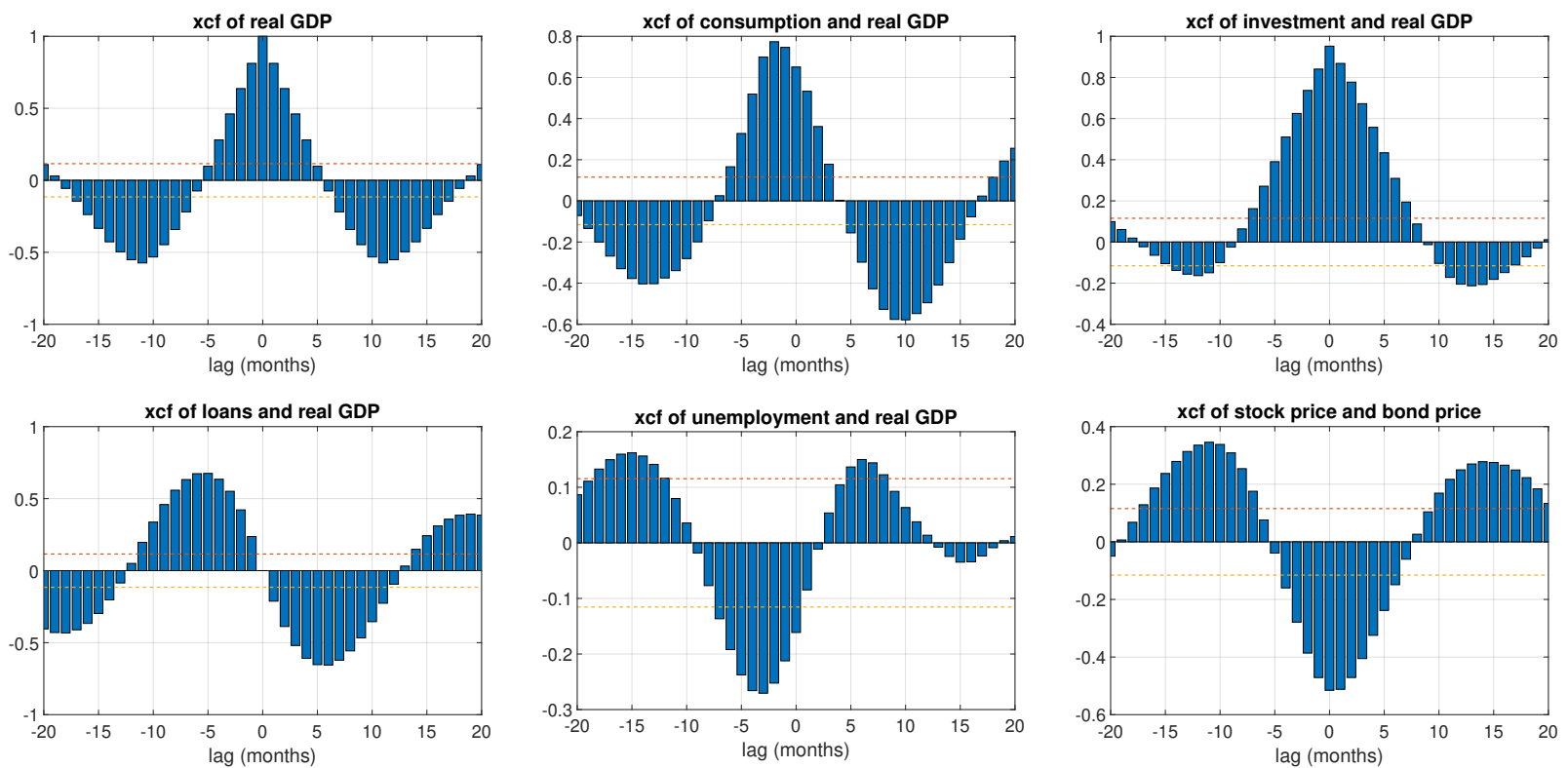

Figure 11: Cross-correlations. Time series considered are monthly and hp filtered.

Concerning the validation of the model, it is worth remarking that Eurace initialization complies with two main requirements: stock-flow consistency and input validation. In particular, we use a specific model's software that is able to initialize the model in an automatic way. We define in this software all the crossrelations between the balance sheet items of the economic agents and we control for the consistency of the process. The initialization starts by setting at 1 the initial value of the nominal monthly wage, and from this reference variable we keep on computing all the others.

In this way we are able to provide an "input validation", where models fitness is ensured by setting 
parameter values and variables ratios according to empirical analysis of actual data ${ }^{17}$.

\subsection{Housing market}

We use the housing market setting described in Ozel et al. (2016). In this framework, the access to the housing market by the households is driven by an exogenous probability $\Phi_{H}$; once in the housing market, households may randomly take the role of buyer or seller, except in the case of fire sale, where households enter in the housing market because are forced to sale their housing units due to financial distress, which is defined as:

$$
\frac{R_{U_{h}}}{Z_{l}+Z_{e}} \geq \Psi_{S}
$$

where $R_{U_{h}}$ is the quarterly payments (principal and interests) related to mortgages $U_{h}$ of household $h, Z_{l}+Z_{e}$ is the sum of quarterly labor and capital income after taxes, and $\Psi_{S}$ is a given threshold. If the financial distress is critically high and steps over a threshold $\iota_{S}$, the household undergoes a mortgage restructuring with a consequent loss on the equity of the credit bank.

It is worth noting that in the eventuality of fire sales, the selling price set by the household is lower than the last average market price $\left(p_{X_{t}}\right)$, in order to increase the probability to sell the housing unit and obtain liquidity. In particular, we distinguish between sell orders and fire sell orders. In the first case, the price set by the household is:

$$
p_{X_{t}}=p_{X}\left(1+\xi \varphi_{H}\right)
$$

where $\xi$ is a random component draw from uniform distribution between 0 and 1 and $\varphi_{H}$ is the maximum percentage price increase of monthly housing price ${ }^{18}$.

In the second case, fire seller households post one of their housing unit for sale at price $p_{X_{t}}$, given by:

$$
p_{X_{t}}=p_{X}\left(1-\xi \varphi_{S}\right)
$$

where $\varphi_{S}$ is the maximum fire sale price reduction.

Households with the buyer role are randomly queued and each buyer in the queue in turn select the cheapest available housing unit to buy and a transaction takes place at the posted sale price. When all buyers had their turn in the housing market or there are no more housing units for sale, the housing market closes and a new housing price $p_{H}$ is computed as the average of the realized transaction prices. This process takes place each month.

Households may buy a housing unit by means of their liquidity resources or, if they are not sufficient,

\footnotetext{
${ }^{17}$ For a detailed decription of model validation see Teglio et al. (2017)

${ }^{18} \mathrm{It}$ is straightforward that households try to sell their housing unit at a price that is higher than market price when they are not facing financial distress
} 
throught a mortgage from a bank. All mortgages last 20 years, and each month the borrowers repay mortgages installments, which are made up of a constant principal component and an variable interest component on remaining installments, computed as central bank interest plus a fixed spread of $1 \%$. The rationale behind this choice is to mimic variable rate mortgages, whose interests are mostly tied to reference rates or indices that are linked with the central bank policy rate (e.g., EURIBOR in Europe). The spread represents the bank's margin. Although we consider a fixed bank's margin that is not linked with households' creditworthiness, it is important to remark that banks check upstream that the applicant borrowers comply with two constrains. In particular, a stock and flow thresholds are included, namely equity to assets ratio (ETA) and debt-serviceto-income ratio (DSTI). Therefore, bank checks that:

- household's net wealth (Equity $E_{h}$ ) to her total wealth (Assets $A_{h}$ ) ratio is higher than a threshold $T_{E T A}:$

$$
\frac{E_{h}}{A_{h}} \geqslant T_{E T A}
$$

- household's debt payments for the upcoming quarter to income is lower than a threshold $T_{D S T I}$ :

$$
\frac{R_{U_{h}}+R_{\widehat{U}_{h}}}{\left(Z_{l}+Z_{e}\right)} \leqslant T_{D S T I}
$$

